Article

\title{
Evaluation of WRF-Chem Predictions for Dust Deposition in Southwestern Iran
}

\author{
Mansour A. Foroushani ${ }^{1, * \mathbb{C}}$, Christian Opp ${ }^{1}$, Michael Groll ${ }^{1}$ and Amirhossein Nikfal ${ }^{2}$ \\ 1 Department of Geography, Philipps-Universität Marburg, 35037 Marburg, Germany; \\ opp@mailer.uni-marburg.de (C.O.); mgroll@gmx.net (M.G.) \\ 2 Atmospheric Science and Meteorological Research Center (ASMERC), Tehran 14965-114, Iran; \\ anik@alumni.ut.ac.ir \\ * Correspondence: mforoushani@students.uni-marburg.de
}

Received: 18 June 2020; Accepted: 14 July 2020; Published: 17 July 2020

\begin{abstract}
The relationships between monthly recorded ground deposition rates (GDRs) and the spatiotemporal characteristics of dust concentrations in southwest Iran were investigated. A simulation by the Weather Research and Forecasting Model coupled with the Chemistry modeling system (WRF-Chem) was conducted for dust deposition during 2014-2015. The monthly dust deposition values observed at 10 different gauge sites (G01-G10) were mapped to show the seasonal and spatial variations in dust episodes at each location. An analysis of the dust deposition samples, however, confirmed that the region along the deposition sites is exposed to the highest monthly dust load, which has a mean value of $2.4 \mathrm{mg} \mathrm{cm}^{-2}$. In addition, the study area is subjected to seasonally varying deposition, which follows the trend: spring $>$ summer $>$ winter $>$ fall. The modeling results further demonstrate that the increase in dust emissions is followed by a windward convergence over the region (particularly in the spring and summer). Based on the maximum likelihood classification of land use land cover, the modeling results are consistent with observation data at gauge sites for three scenarios [S.I, S.II, and S.III]. The WRF model, in contrast with the corresponding observation data, reveals that the rate factor decreases from the southern [S.III-G08, G09, and G10] through [S.II-G04, G05, G06, and G07] to the northern points [S.I-G01, G02, and G03]. A narrower gap between the modeling results and GDRs is indicated if there is an increase in the number of dust particles moving to lower altitudes or an increase in the dust resident time at high altitudes. The quality of the model forecast is altered by the deposition rate and is sensitive to land surface properties and interactions among land and climate patterns.
\end{abstract}

Keywords: dust deposition rate; WRF-Chem; climate zone; Iran

\section{Introduction}

Small solid and dry particles can remain suspended in the Earth's atmosphere for a sufficiently long time to extensively affect the weather and climate [1-3]. When particles are airborne, they can affect the radiation balance by scattering and absorbing radiation (e.g., [4]) in addition to the immediate threat they pose to the atmosphere and satellite retrievals (e.g., [5]). Dust also significantly affects air quality and causes considerable impairments to societal health, specifically human health [6-8] and infection. Moreover, dust can affect agriculture [9], engines, and technical infrastructure (e.g., [10]), thereby causing severe economic damages. Models that predict dust behavior can improve our understanding of dust process and its effects. However, a detailed knowledge of how dust is activated, including the characteristics of activation, dust transport routes, and deposition processes, is crucial to fully understand its complexity [11]. 
The dynamical core of the Weather Research and Forecasting (WRF) model includes several numerical approaches, such as model initialization, boundary conditions, physics options, and gridnesting techniques [12]. Physical and Planetary Boundary Layer (PBL) parameterization is required to model small-scale processes, such as precipitation, which generally cannot be numerically discretized by the model (e.g., [13]). The WRF coupled with the Chemistry modeling system (WRF-Chem) can be configured to include indirect aerosol effects, which can enhance the results for precipitation (e.g., [14]). This option is particularly beneficial for modeling the spatiotemporal behavior of gaseous particles such as acid rain simulation in urban areas (e.g., [15]). Geological and terrain features, such as the soil texture and land use, are the leading causes of dust emission $[16,17]$. However, considering the details of the life of dust particles, WRF-Chem models have also been used to simulate and investigate dust-climate interactions $[15,18]$. Recently, great progress has been made in understanding dust processes by modeling the dust source function and numerically simulating dust events in West Asia (e.g., [19]). Many researchers have attempted to evaluate model simulation data using air quality station data and Aerosol Optical Thickness (AOT) observations over the AErosol RObotic NETwork (AERONET) (e.g., [20]) or retrieved from satellites with in situ measurements [21]. In other studies, dust emission fluxes in atmospheric models have been mainly parameterized by several atmospheric and geological factors (e.g., [22]), such as the wind speed and soil structure. In wind simulations, good performance of the WRF numerical model for dust emissions is vital and consequently influences the model results of dust concentrations (e.g., [14]).

Furthermore, soil erodibility is a crucial factor for identifying dust sources and estimating the dust emission flux from the surface $[23,24]$. A higher erodibility could make the soil more susceptible to erosion, which would lead to a larger dust emission [25]. In numerous dust models, a global dust source function, as presented in [26], is used. This source function, $S\left(Z_{i}\right)$, is based on the topography and estimates the probability that soil sediments will accumulate at a specific location as follows:

$$
\mathrm{S}=\left(\left(\mathrm{Z}_{\max }-\mathrm{Z}_{\mathrm{i}}\right) /\left(\mathrm{Z}_{\max }-\mathrm{Z}_{\min }\right)\right)^{5},
$$

where $Z_{i}$ is the altitude that is normalized by the $Z_{\max }$ and $Z_{\min }$ heights over an area of $10^{\circ} \times 10^{\circ}$ around the $\mathrm{i}^{\text {th }}$ grid point. $S$ is the erodibility factor for the $\mathrm{i}^{\text {th }}$ grid of the model.

Recently, numerous studies have evaluated the dust deposition rates and the physical and chemical characteristics of dust in Iran (e.g., [27,28]) and worldwide (e.g., [29,30]). Previous studies have indicated influences of the PBL and the land surface on the calculation of aeolian feedback and these relationships were used to determine the soil moisture and its corresponding relationships with atmosphere, land, and transport processes (e.g., [31]).

Although previous research compared the impacts of model processes from WRF-Chem prediction relative to those from different methods of observation, very few works have reported on the effectiveness of using ground deposition rates (GDRs) as ground-based observations combined with model outputs from WRF-Chem. Given the lack of existing literature, this study aimed to provide ground-based observations based on more detailed information about the dust episode in the region. The second aim was to demonstrate the beneficial impact of GDR observations on the output of the WRF-Chem model.

The outline of this paper is as follows. In Section 2, the study area is illustrated, and the land surface and climate maps, which include the experimental design of the gauge sites (geo-coordination), are explained. The approaches and methodology of sampling and the model simulation are clarified in Section 3. The mean results and climate factors of the dust sampling analysis are provided in Section 4 . The seasonal and spatial variations in the dust deposition and concentration rates were extensively investigated. An evaluation of the model based on quantifying the dust load and dust concentration and a discussion of the climate factor and dust behavior is given in Section 5.2. 


\section{Study Area}

Aeolian dust is a highly common phenomenon in southwest Iran and reaches annual mean concentrations of 50-100 $\mathrm{\mu g} \mathrm{m}^{-3}$ [32]. Airborne dust flows north and eastward from the Saudi Arabian and Iraqi deserts of southern and southwestern Iran daily [33]. Therefore, an area of approximately $117,000 \mathrm{~km}^{2}$ was chosen for the sampling sites, which are located in southwest Iran between $45^{\circ} 30^{\prime} 00^{\prime \prime} \mathrm{E}$ and $49^{\circ} 30^{\prime} 00^{\prime \prime} \mathrm{E}$ and between $30^{\circ} 00^{\prime} 00^{\prime \prime} \mathrm{N}$ and $35^{\circ} 00^{\prime} 00^{\prime \prime} \mathrm{N}$. The study area includes the provinces of Khuzestan, Lorestan, and Kermanshah. Thus, the area is characterized by rolling mountains in the north and east and a plain and marshland in the south. The study area is located in a region with cold and hot desert climates [34].

In this study, a land cover condition was applied to provide information on the recent land use and land cover (LULC) pattern in the research area and to classify each gauge center with respect to the Land Use/Cover Area framework of the Statistical Survey (LUCAS). Additionally, the research area included five major classifications: artificial $(6.5 \%)$, industrial $(0.05 \%)$, wet land $(4.5 \%)$, vegetation $(27 \%)$, and bare land $(61 \%)$.

The resultant LULC maps of the study area include details from the gauge sites and are shown in Figure 1. The geographic bias information for the area, meteorological data, climate data, and LUCAS information adjacent to the selected point are discussed in the Section 5.

\subsection{Setting Sites and Data}

Table 1 shows that the sites were coded as G01-G10 and located based on the distribution and intensity of the dust events reported in the annual report of Iran Meteorological Organization (2014) [35]. Twenty samplers were constructed and placed at 10 gauge sites and the dominant local features were observed.

Table 1. Location, Altitude, and Total Distance of Dust Samplers.

\begin{tabular}{|c|c|c|c|c|c|c|c|}
\hline \multirow{2}{*}{$\begin{array}{l}\text { No } \\
1\end{array}$} & \multirow{2}{*}{$\begin{array}{c}\text { LULC Based on LUCAS } \\
\text { Bare and Artificial }\end{array}$} & \multirow{2}{*}{$\begin{array}{c}\text { Code } \\
\text { G01 }\end{array}$} & \multicolumn{2}{|c|}{ Geo-Coordinate } & \multirow{2}{*}{$\begin{array}{c}\text { Climate } \\
\text { Arid Steppe Hot } \\
{[\text { BSh] }}\end{array}$} & \multirow{2}{*}{$\begin{array}{c}\begin{array}{c}\text { Altitude } \\
\text { (m) }\end{array} \\
144\end{array}$} & \multirow{2}{*}{$\begin{array}{c}\begin{array}{c}\text { Distance } \\
\text { (km) }\end{array} \\
0\end{array}$} \\
\hline & & & 34.000553 & 45.497595 & & & \\
\hline 2 & Bare & G02 & 34.007182 & 45.499075 & $\begin{array}{l}\text { Arid Steppe Hot } \\
\text { [BSh] }\end{array}$ & 184 & 1 \\
\hline 3 & Bare & G03 & 34.393584, & 45.648174 & $\begin{array}{c}\text { Arid Steppe Hot } \\
\text { [BSh] }\end{array}$ & 394 & 51 \\
\hline 4 & Bare and Vegetation & G04 & 34.423028, & 45.993753 & $\begin{array}{c}\text { Temperate Hot } \\
\text { [Csa] }\end{array}$ & 910 & 61 \\
\hline 5 & Bare, Vegetation, and Artificial & G05 & 34.353365 & 47.101335 & $\begin{array}{l}\text { Temperate Hot } \\
\text { [Csa] }\end{array}$ & 1304 & 132 \\
\hline 6 & Bare and Vegetation & G06 & 33.024976, & 47.759393 & $\begin{array}{c}\text { Temperate Hot } \\
\text { [Csa] }\end{array}$ & 581 & 387 \\
\hline 7 & Vegetation and Wet area & G07 & 32.380038, & 48.282664 & $\begin{array}{l}\text { Arid Steppe Hot } \\
\text { [Bsh] }\end{array}$ & 109 & 101 \\
\hline 8 & Bare, Wet area, and Vegetation & G08 & 31.445194, & 48.632398 & $\begin{array}{l}\text { Arid Desert Hot } \\
\text { [BWh] }\end{array}$ & 25 & 127 \\
\hline 9 & Bare, Water, and Artificial & G09 & 30.584651, & 49.163632 & $\begin{array}{c}\text { Arid Desert Hot } \\
\text { [BWh] }\end{array}$ & 6 & 131 \\
\hline 10 & Bare and Artificial & G10 & 30.352411, & 48.292293 & $\begin{array}{l}\text { Arid Desert Hot } \\
\text { [BWh] }\end{array}$ & 2 & 100 \\
\hline
\end{tabular}

Table contents are modified based on climate pattern and adapted from [28]. 

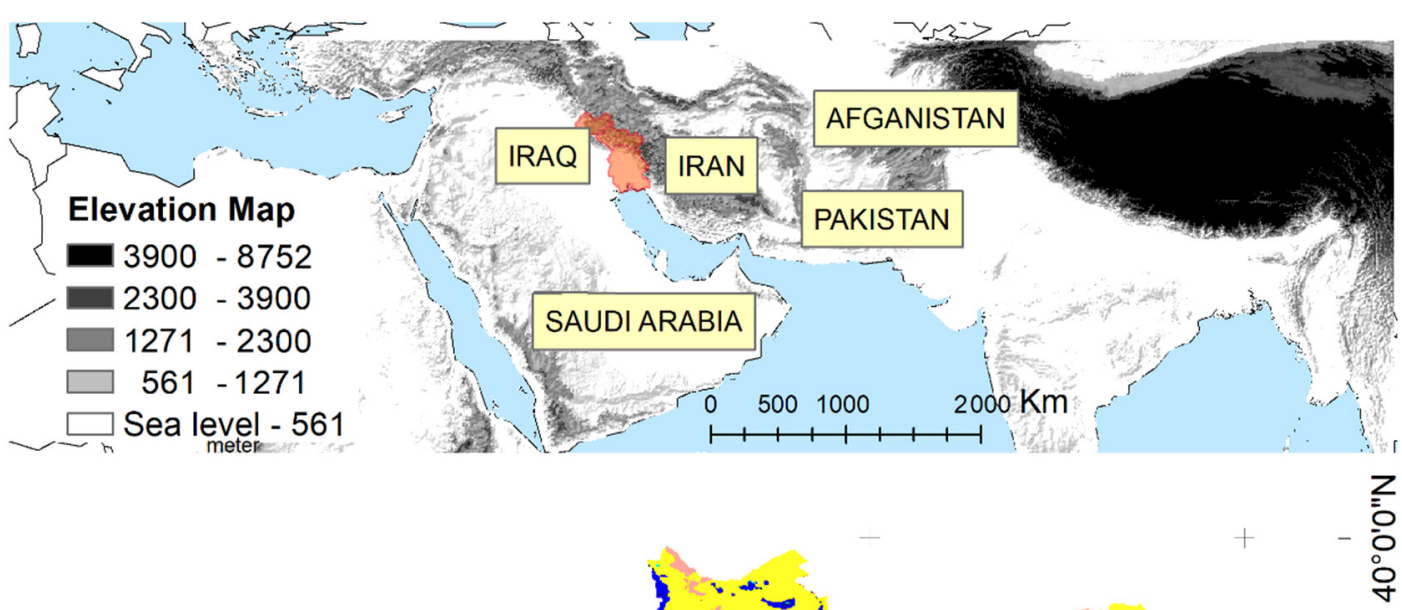

Climate Over Iran [Geiger Köppen]

[Dsa] Cold \& warm summer

[Dsb] Cold \& Dry Hot Summer

[Csa] Temperate Hot \& Dry Summer

[BWh] Arid Desert Hot

[BSh] Arid Steppe Hot
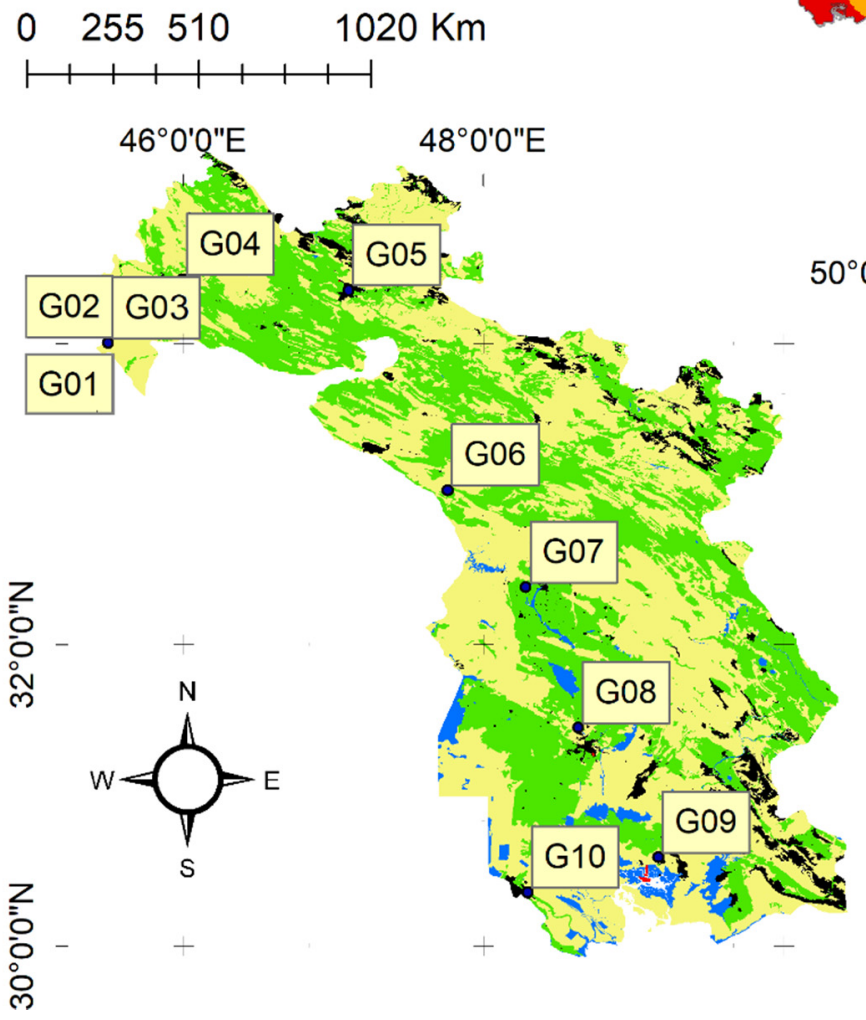

Land use land cover (LUCAS)

- Gauge_Sites

Artificial land

Bareland

Industrial

Vegetation

Wet area - Sheet of water -

\section{$0 \quad 62.5125 \quad 250 \mathrm{Km}$}

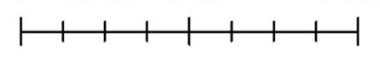

Figure 1. Mapping the LULC on the gauge site distribution. (Top) The study area from the map (light red). Digital Elevation models (DEMs) are available globally and have a resolution of approximately $1 \mathrm{~km}$ from GTOPO30; they have been obtained through the USGS Explorer dataset GTOPO30 [36]. (Middle) The climate map shows the climate classification over the country [34]. Information adjacent to the selected point are discussed in Section 4.1. (Bottom) The land use land classification map retrieved from the Landsat satellite from summer 2012 from The United States Geological Survey (USGS) Earth Explorer. 


\subsection{Climatic Characteristics}

Following the work of Russell (1931) [37], the Köppen climate classification scheme was used; this scheme uses three letters to represent world climates and divides the climate into five main climate groups at a resolution of $1 \mathrm{~km}$ [34].

These main groups are as follows: A (tropical), B (dry), C (temperate), D (continental or cold climate), and $\mathrm{E}$ (polar). The second letter indicates the seasonal precipitation type for steppe (S) and desert $(\mathrm{W})$ environments. Alternately, $\mathrm{f}, \mathrm{m}, \mathrm{w}$, and s represent rain force, monsoon, savanna-wet, and savanna-dry, respectively. The third letter indicates the level of heat, with cold indicated by $\mathrm{K}$ and hot indicated by $h$. The letters a-d represent hot summer (a), warm summer (b), cold summer (c), and very cold winter (d) climates, respectively (Table 2). The climate of the study area was classified using the aforementioned classification scheme, which has been previously applied by other researchers (e.g., [38]).

Table 2. Climate Classification Scheme of the Study Area.

\begin{tabular}{ccc}
\hline Type & Description & Criterion \\
\hline B & Arid climate & Pann $<10$ Pth \\
BS & Arid steppe climate & Pann $>05$ Pth \\
BW & Arid desert climate & Pann $\leq 5$ Pth \\
\hline C & Warm temperate climate & $-3{ }^{\circ} \mathrm{C}<\mathrm{Tmin}<+18^{\circ} \mathrm{C}$ \\
Cs & Warm temperate climate, with dry summer & Psmin $<$ Pwmin, Pwmax $>2$ Psmin and Psmin $<40 \mathrm{~mm}$ \\
Cw & Warm temperate climate, with dry winter & Pwmin $<$ Psmin and Psmax $>10$ Pwmin \\
Cf & Warm temperate climate, fully humid & Neither Cs nor Cw \\
\hline D & Snow climate & Tmin $\leq-3{ }^{\circ} \mathrm{C}$ \\
Ds & Snow climate, with dry summer & Psmin $<$ Pwmin.Pwmax $>3$ Psmin and Psmin $<40 \mathrm{~mm}$ \\
Dw & Snow climate, with dry winter & Pwmin $<$ Psmin and Psmax $>10$ Pwmin \\
Df & Snow climate, with fully humid & Neither Ds nor Dw \\
\hline C
\end{tabular}

Climate of the study areas were classified using the Köppen climate classification scheme [38] and indicated by three letters that represent the five main climate groups at a resolution of $1 \mathrm{~km}$ [34].

\section{Approaches and Methodology}

To understand the impact of the physical distribution of dust in southwest Iran, the sampling sites over the LULC of the study area were classified. The GDR data, coupled with the WRF-Chem model, revealed the severity of the physical distribution of the aeolian dust over the study area.

\subsection{Ground Observation, Sites and Sampling}

\subsubsection{Data Sampling Method and Analysis}

Both gravimetric and directional dust samplers were constructed and installed $2 \mathrm{~m}$ above the ground at G01-G10 (Figure 2) to observe the deposited particulate matter that settled from the air [28]. The sampler design was deliberately kept simple to ensure long-term durability and easy maintenance [39,40]. Each sampler consisted of a plastic container with a radius of $10 \mathrm{~cm}$ and a paper inlay for passive dust collection. 

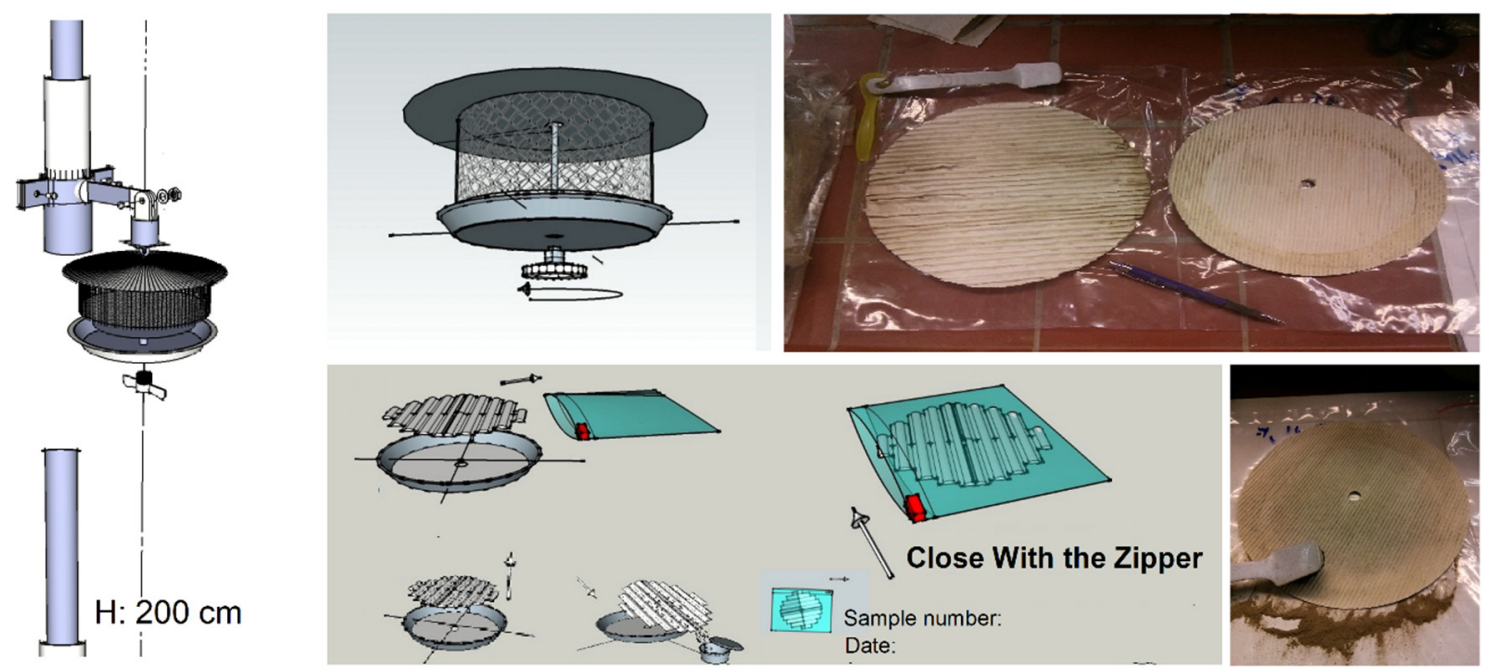

Figure 2. Installation and sampling technique; modified photos by courtesy of [28].

\subsubsection{LULC on the Gauge Sites}

The global environment, ecological functions, and structures are affected by the LULC. Thus, the LULC illustrates the evolution of the ecological function in a human-environment system (e.g., [41]). In this system, numerous drivers interact with different feedbacks, and the consequent interactions affect the development pattern [42]. In several cases of aeolian dust in North Africa, Southwest Asia, Southwest USA, and China (Inner Mongolia), repeated droughts and possible consequences of climate variability, such as desertification, are of interest to numerous scientists. In southwest Asia, several areas, such as west Iran, are much more prone to dust storms than other areas due to differences in soils and climate [43]. To enhance the identification of dust events in the study area using GDR data, various biophysical categories were distinguished, such as the areas of vegetation (e.g., trees, bushes, crops, grasses, and herbs), artificial land (building, industries, and road), bare soil, or bare land (rock, sand, and areas with no dominant vegetation cover on at least $90 \%$ of the area) cover, and wet areas and bodies of water (sheets of water, watercourses, and wetland). As shown in Figure 3, a given circle centered (with a radius of $10 \mathrm{~km}$ ) at each gauge site (G01-G10) represents the spatial pattern of the LULC. This analysis represents the whole area with respect to each sampler at the gauge site. 


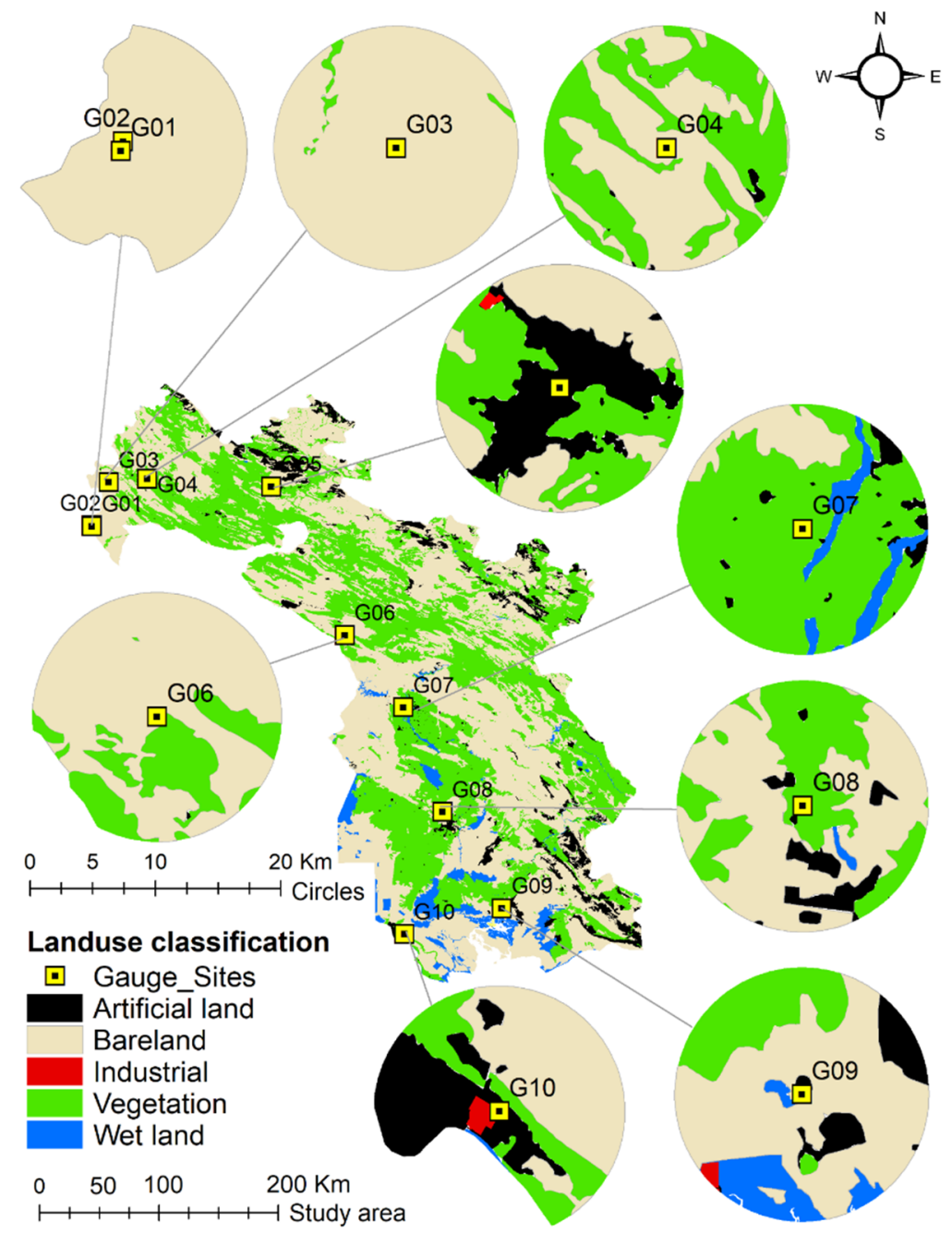

Figure 3. Circle centered at each gauge site representing the LULC within a radius of $10 \mathrm{~km}$. A given circle centered (with a radius of $10 \mathrm{~km}$ ) at each gauge site (G01-G10) represents the spatial pattern of the LULC. This analysis represents the whole area with respect to each sampler at the gauge site.

\subsection{Setting WRF-Chem Model Simulation}

Several atmospheric and environmental variables, such as the dust concentration and dust load, as well as the wind direction and speed over the deposition sites, were simulated by the WRF-Chem model (V3.9.1) [12,44]. Under the planetary and boundary layer conditions required to run the WRF model, the reanalysis product of the European Center for Medium-Range Weather Forecasts, called the ERA-Interim data [45], which has a spatial resolution of $0.75^{\circ} \times 0.75^{\circ}$, were acquired to run the WRF-Chem model. ERA-Interim data are a global atmospheric reanalysis dataset available for the period from 1979 to 31 August 2019 and is provided by the models and data assimilation systems of the European Centre for Medium-Range Weather Forecasts. For this study, dust-only simulations were performed for two periods: March to April 2014 and January to February 2015. Figure 4 shows the simulation domains. The spatial resolutions of the main domain and subdomain are $30 \mathrm{~km} \times 30 \mathrm{~km}$ and $10 \mathrm{~km} \times 10 \mathrm{~km}$, respectively. 


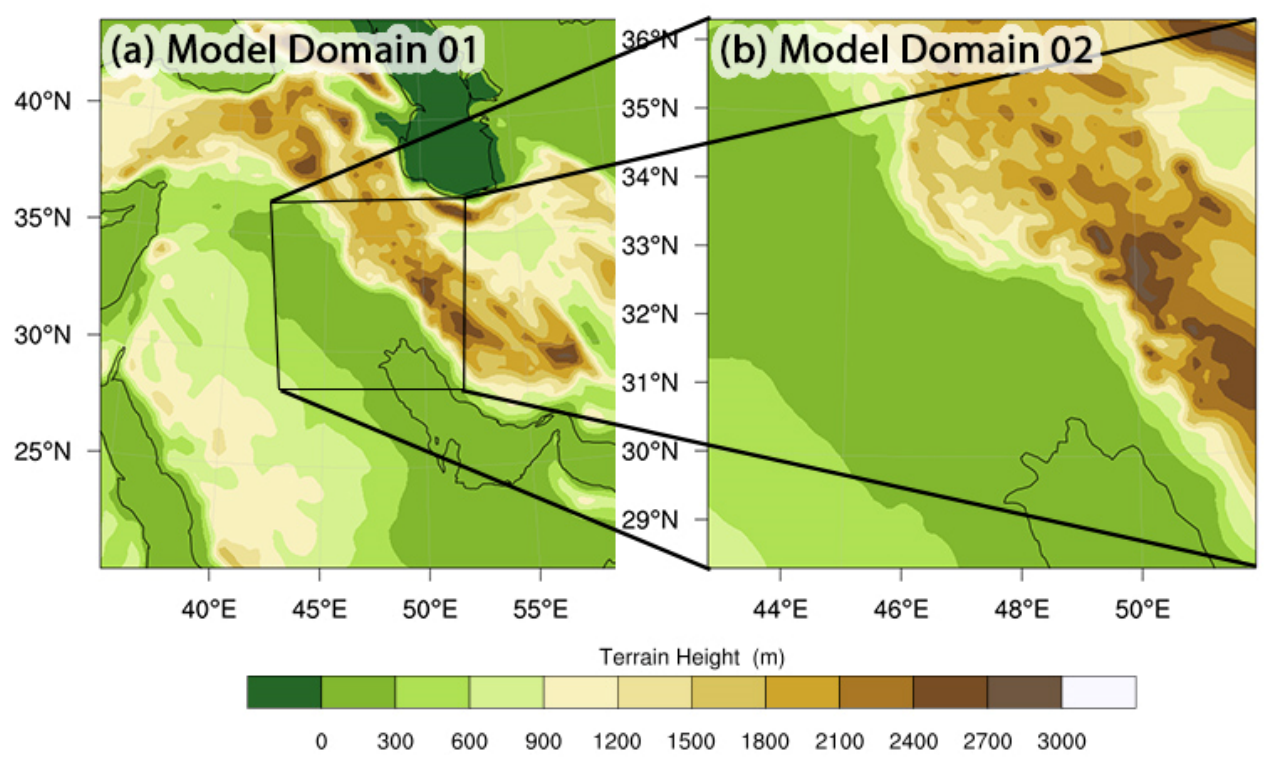

Figure 4. Simulation domain: the spatial resolution of the main domain is $30 \mathrm{~km} \times 30 \mathrm{~km}$ (left); and the spatial resolution of the subdomain is $10 \mathrm{~km} \times 10 \mathrm{~km}$ (right).

Several physical options that have been highly tested and produced reasonable results were set as the physical options of the WRF model (Table 3). These standard options were introduced in the WRF model as the physics suites, beginning in version 3.9 .

Table 3. Configuration Options for the WRF-Chem Model for Dust.

\begin{tabular}{cc}
\hline Physical Option & Setting \\
\hline Microphysics & New Thompson et al. scheme \\
Cumulus Parameterization & Tiedtke scheme (U. of Hawaii version) \\
Longwave Radiation & RRTMG (Rapid Radiative Transfer Model for GCMs) scheme \\
Shortwave Radiation & RRTMG (Rapid Radiative Transfer Model for GCMs) shortwave \\
Surface Layer & Eta similarity \\
Land Surface & Noah Land Surface Model \\
Planetary Boundary layer & Mellor-Yamada-Janjic scheme \\
\hline
\end{tabular}

\section{Results}

\subsection{Experiment, Sites and Sampling Result}

\subsubsection{Climate and LULC for Each Site}

As shown in Table 4, the gauge sites were subclassified into three main climate zones: [BWh], [BSh], and [Csa]. Arid desert climates and hot [BWh] climates are represented in the northern coastal plains of the Persian Gulf between the latitudes of $30^{\circ} \mathrm{N}$ and $31^{\circ} \mathrm{N}$. The next climate zone represents an arid steppe hot zone [BSh], which is located between $34^{\circ} \mathrm{N}$ and $32^{\circ} \mathrm{N}$. A temperate climate with a warm and hot summer zone [Csa] is located between $33^{\circ} \mathrm{N}$ and $34^{\circ} \mathrm{N}$, starting in the extreme western region. Additional results were calculated to improve estimations of the dust load, concentration, and deposition and are described in the Discussion section. 
Table 4. Land Cover in the Study Area.

\begin{tabular}{ccccccccccc}
\hline \multicolumn{10}{c}{ Sampler and Gauge Site Number Land Cover in Total Area of Study (\%) } \\
\hline Longitude [E] & $45-46$ & $45-46$ & $45-46$ & $46-47$ & $47-48$ & $47-48$ & $48-49$ & $48-49$ & $49-50$ & $48-49$ \\
\hline Latitude [N] & $33-34$ & $33-34$ & $33-34$ & $33-34$ & $33-34$ & $32-33$ & $32-33$ & $31-32$ & $30-31$ & $30-31$ \\
Climate & BSh & BSh & BSh & BSh-Csa & Csa & Csa-BSh & BSh & BWh & BWh & BWh \\
Gauge sites & G01 & G02 & G03 & G04 & G05 & G06 & G07 & G08 & G09 & G10 \\
\hline Artificial & 0.07 & 0.07 & 0.00 & 0.95 & 32.49 & 0.11 & 4.33 & 8.18 & 9.09 & 24.81 \\
Bareland & 99.93 & 99.93 & 98.85 & 50.90 & 33.11 & 72.90 & 10.32 & 57.94 & 60.41 & 36.43 \\
Industrial & 0.00 & 0.00 & 0.00 & 0.00 & 0.47 & 0.00 & 0.00 & 0.00 & 0.68 & 1.58 \\
Vegetation & 0.00 & 0.00 & 1.56 & 48.66 & 34.22 & 27.00 & 77.48 & 33.10 & 19.07 & 14.91 \\
Wet land & 0.00 & 0.00 & 0.00 & 0.00 & 0.00 & 0.00 & 8.40 & 0.79 & 10.76 & 22.27 \\
\hline Total & 100 & 100 & 100 & 100 & 100 & 100 & 100 & 100 & 100 & 100 \\
Accuracy & 0.00 & 0.00 & +0.40 & +0.50 & +0.30 & 0.00 & +0.50 & 0.00 & 0.00 & 0.00 \\
\hline
\end{tabular}

The gauge sites, area for each site with a radius of $10 \mathrm{~km}$.

In the following section, we authentically represent the relative atmospheric state using GDR data, including the wind magnitude, precipitation, and temperature These parameters have been hypothesized to reflect the increase or decrease in the aeolian deposition rate under the LULC classification (e.g., [46]).

\subsubsection{Meteorological Data}

In general, the highest wind speeds occurred in the late spring, summer, and early autumn in the eastward direction (1.0-2.5 $\left.\mathrm{m} \mathrm{s}^{-1}\right)$. In contrast, the lowest speeds occurred in the winter and spring. The wind speed in the winter was approximately zero in the northward direction, whereas it exceeded that of the eastward direction $\left(1.5 \mathrm{~m} \mathrm{~s}^{-1}\right)$ in the spring throughout the study area. An existing study about an Asian dust storm showed that dust events can be recognized on the basis of the total suspended dust particulate matter (TSP) in combination with the visibility and wind speed [47]. The study suggested that a wind threshold of $17 \mathrm{~m} \mathrm{~s}^{-1}$ can decrease visibility to $1000 \mathrm{~m}$ if the TSP is less than $2000 \mu \mathrm{g} \mathrm{m}^{-3}$. In addition, a wind threshold of $5-10 \mathrm{~m} \mathrm{~s}^{-1}$ on TSP $\left(<500 \mu \mathrm{g} \mathrm{m}^{-3}\right)$ and visibility ( $2000 \mathrm{~m}$ ) has been identified from a study on northeast Asian Dust [48]. In addition to wind thresholds, our results are also in agreement with a finding reported that eastward and southward wind speeds varied from 1 to $6 \mathrm{~m} \mathrm{~s}^{-1}$ during dust events [49].

The mean value of the monthly precipitation was $37.70 \mathrm{~mm}$ (Historical climate data, 2016; Iran Meteorological Organization, 2014), whereas the precipitation per month was notably below average in the summer and winter and above that in the spring and fall. The precipitation in June, July, and August can be classified as zero-rain $\left(0-1.8 \mathrm{~mm} \mathrm{month}^{-1}\right)$ when deficits in precipitation occurred. However, light rain (18-180 $\mathrm{mm} \mathrm{month}^{-1}$ ) events, where the precipitation was below the mean value, were recorded in May, September, and October. In contrast, the rainfall in November, December, February, March, and April indicated a value of approximately $50 \mathrm{~mm}$, which is above average.

Ambient monthly temperatures were observed during nearly the entire fieldwork period. The mean temperature was generally much higher than $16^{\circ} \mathrm{C}$. A long period of high temperature points fluctuated between 29 and $43^{\circ} \mathrm{C}$ in the summer. The annual minimum temperature was also warmer than the minimum temperature in the winter, which experienced a minimum value of $-8^{\circ} \mathrm{C}$. This temporal pattern was also detected by National Oceanic and Atmospheric Administration (NOAA) researchers [50]; they determined 2015 to be the warmest year on record for Asia and South America and recorded a global temperature deviation of $0.90^{\circ} \mathrm{C}$ above average for the period of 1901-2000. Furthermore, this study is, thus, in accordance with the results of Alizadeh-Choobari and Najafi (2018) [51], which are as important as the aforementioned results and state that a rise in temperature is associated with a decrease in total annual precipitation. Higher temperatures are generally associated with lower precipitation amounts and vice versa. This observation is expected because the $[\mathrm{BWh}]$ and [Csa] regions are associated with more sunshine and less evaporative cooling. 


\subsubsection{Dust Sampling Analysis}

The dust event frequency (DEF) with the deposition rates are listed in Table 5. In general, a high magnitude $\left(\mathrm{mg} \mathrm{cm}^{-2}\right)$ of DEF was observed in G09, G10, G01, and G02. Table 5 indicates a strong correlation between the DEF values and GDRs for sites G01, G03, G04, G07, G08, G09, and G10. Correlation magnitudes of $0.35,0.49$, and 0.69 were obtained for the GDRs $\left(\mathrm{mg} \mathrm{cm}^{-2}\right)$ of G05, G02, and G08, respectively.

Ordinary inverse distance weighted (IDW) interpolation technique was applied to identify the average seasonal magnitude of the GDRs obtained from the 10 gauge sites (Figure 5); it demonstrates that the average seasonal GDRs ranged from 0.3 to $2.0 \mathrm{mg} \mathrm{cm}^{-2}$, which corresponds to monthly field deposition rates in the range of 3-20 ton $\mathrm{km}^{-2}$. In general, higher deposition rates occurred in the spring, summer, and winter.
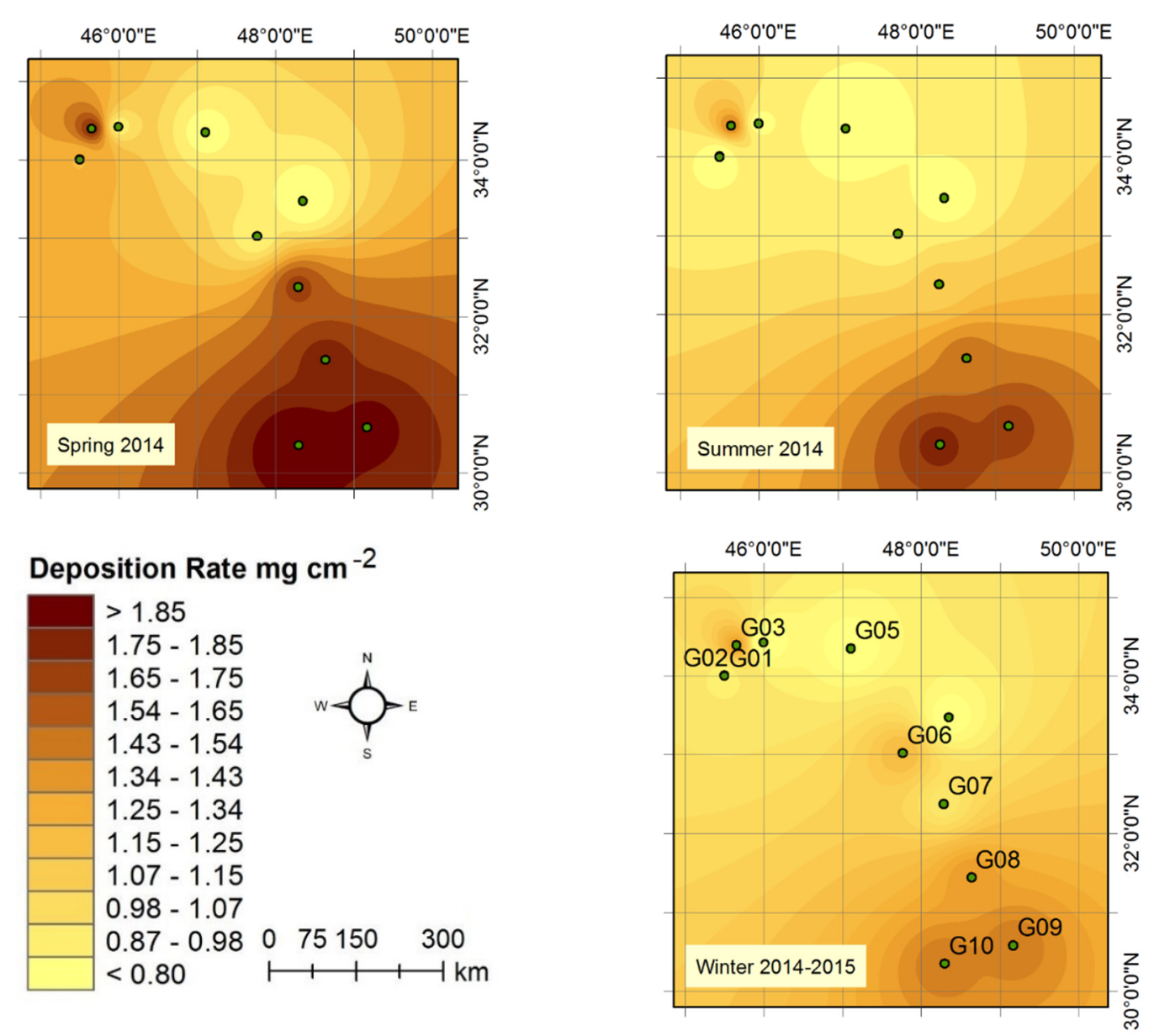

Figure 5. Maps showing the seasonal dust deposition rates $\left(\mathrm{mg} \mathrm{cm}^{-2} \mathrm{month}^{-1}\right)$. 
Table 5. Dust Deposition Rates vs. DEF.

\begin{tabular}{|c|c|c|c|c|c|c|c|c|c|c|c|c|c|c|c|c|c|c|c|c|c|}
\hline \multicolumn{10}{|l|}{ Chronic } & \multicolumn{12}{|c|}{ Sample Sites G01-G10 $\mathrm{mg} \mathrm{cm}^{-2}$} \\
\hline Month & Year & G01 & DEF & G02 & DEF & G03 & DEF & G04 & DEF & G05 & DEF & G06 & DEF & G07 & DEF & G08 & DEF & G09 & DEF & G10 & DEF \\
\hline March & 2014 & 0.6 & 1 & 0.8 & 1 & 0.2 & 0 & 0.2 & 0 & 0.5 & 0 & 0.2 & 0 & 0.2 & 0 & 0.7 & 1 & 0.6 & 1 & 1.0 & 2 \\
\hline April & 2014 & 2.6 & 4 & 2.0 & 3 & 0.5 & 1 & 2.0 & 0 & 0.2 & 0 & 0.2 & 0 & 1.0 & 0 & 0.5 & 0 & 0.9 & 1 & 0.8 & 1 \\
\hline May & 2014 & 1.0 & 2 & 0.5 & 2 & 0.3 & 1 & 3.0 & 0 & 0.3 & 0 & 0.1 & 0 & 0.5 & 0 & 0.2 & 0 & 0.5 & 0 & 0.2 & 0 \\
\hline June & 2014 & 1.5 & 2 & 0.8 & 2 & 0.8 & 1 & 0.2 & 0 & 1.0 & 0 & 0.2 & 0 & 0.5 & 1 & 0.6 & 1 & 1.0 & 1 & 1.0 & 1 \\
\hline July & 2014 & 0.8 & 1 & 0.5 & 1 & 0.8 & 1 & 0.2 & 0 & 0.9 & 0 & 0.3 & 0 & 0.6 & 1 & 1.9 & 1 & 1.2 & 1 & 0.9 & 1 \\
\hline August & 2014 & 1.5 & 2 & 1.0 & 2 & 0.9 & 1 & 0.0 & 0 & 2.0 & 0 & 0.6 & 0 & 0.3 & 1 & 2.0 & 1 & 1.8 & 2 & 2.1 & 3 \\
\hline September & 2014 & 1.5 & 2 & 1.5 & 2 & 0.9 & 1 & 0.5 & 0 & 1.0 & 0 & 0.9 & 0 & 0.2 & 0 & 0.6 & 0 & 0.9 & 1 & 0.9 & 1 \\
\hline October & 2014 & 0.9 & 1 & 0.6 & 1 & 0.2 & 0 & 0.2 & 0 & 0.1 & 0 & 0.0 & 0 & 0.2 & 0 & 0.3 & 0 & 0.3 & 0 & 0.3 & 1 \\
\hline November & 2014 & 2.0 & 0 & 0.9 & 0 & 0.2 & 0 & 0.2 & 0 & 0.1 & 0 & 1.0 & 0 & 0.2 & 0 & 0.2 & 0 & 0.5 & 0 & 0.2 & 0 \\
\hline December & 2014 & 1.5 & 0 & 0.2 & 0 & 0.1 & 0 & 0.2 & 0 & 0.2 & 0 & 0.2 & 0 & 0.9 & 0 & 0.3 & 0 & 0.3 & 0 & 1.0 & 0 \\
\hline January & 2015 & 1.8 & 2 & 1.0 & 2 & 0.8 & 1 & 0.6 & 1 & 0.2 & 0 & 0.3 & 0 & 2.5 & 3 & 2.0 & 3 & 2.5 & 4 & 3.1 & 5 \\
\hline February & 2015 & 0.5 & 1 & 0.4 & 1 & 0.6 & 1 & 0.2 & 0 & 0.2 & 0 & 0.1 & 0 & 1.7 & 0 & 0.8 & 1 & 1.5 & 1 & 1.1 & 1 \\
\hline March & 2015 & 0.8 & 1 & 0.3 & 0 & 0.4 & 0 & 0.5 & 1 & 0.6 & 1 & 0.2 & 0 & 1.0 & 1 & 0.9 & 0 & 0.7 & 0 & 2.1 & 0 \\
\hline Average & & 1.20 & & 0.80 & & 0.50 & & 0.30 & & 0.30 & & 0.30 & & 0.70 & & 0.80 & & 1.00 & & 1.10 & \\
\hline Correlation & & 0.96 & & 0.49 & & 0.81 & & 0.73 & & 0.35 & & 0.00 & & 0.85 & & 0.69 & & 0.93 & & 0.74 & \\
\hline$p$-Value $<$ & & 0.05 & & 0.05 & & 0.05 & & 0.05 & & NA & & NA & & 0.05 & & 0.05 & & 0.05 & & 0.05 & \\
\hline
\end{tabular}

Dust deposition rates (Weight in $\mathrm{mg} \mathrm{cm}^{-2}$ ) and DEF in the grey columns (events/month) for the sites G01-G10 during 2014 and March 2015, as well as the Pearson correlation for each station. Reprinted from [28]. 
Overall, the seasonal adjustment shows (Figure 6) that, after February 2014, the deposition rate ( $\mathrm{mg} \mathrm{cm}^{-2}$ ) rose sharply to 1.3, increased to 1.4 in March and April, and remained constant in May (1.3). The GDR values fluctuated between 1.3 and $1.4 \mathrm{mg} \mathrm{cm}^{-2}$ during the spring and summer and dropped sharply to $0.7 \mathrm{mg} \mathrm{cm}^{-2}$ in September. Again, the deposition rate rose slowly in October, and then steadily declined, reaching a minimum in December. In January 2015, it underwent a sudden increase, and the deposition rate almost recovered to its maximum rate of 1.5 in February. Finally, the rate dropped by $1.2 \mathrm{mg} \mathrm{cm}^{-2}$ in March. By all means, the highest deposition rate occurred in the spring, and the lowest in the fall, based on the high negative correlation between the GDR and precipitation. This contribution is consistent with the observations of Trenberth (2011), who revealed that highest dust deposition rates in early summer could be caused by dusty winds and low humidity. In addition, the lowest dust deposition rates occurred in autumn when heavy rainfalls occurred during the sampling time. Observations of the different climate regions however, together with seasonal dust events, denote that some areas are much more prone to dust storms than other areas due to differences in climate. Thus, the highest deposition rate in the Gansu province of China [49] occurred in the spring. However, with a slight offset, the highest seasonal deposition rate in northern Kuwait [52] occurred in the winter, with the rates in spring, summer, and autumn decreasing in that order.

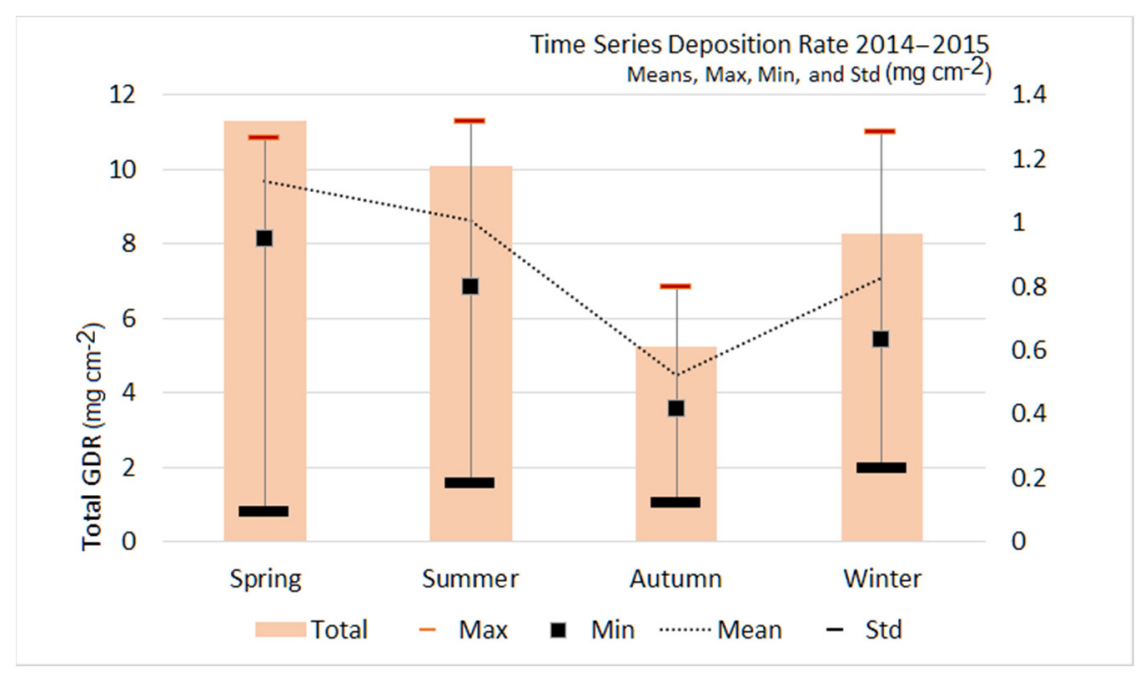

Figure 6. Seasonal average deposition rate gathered from the GDR.

The seasonal deposition trend is as follows: spring $>$ summer $>$ winter $>$ fall. The highest GDR value was exhibited in spring $\left(11 \mathrm{mg} \mathrm{cm}^{-2}\right)$, and the fall season showed deposition rates $\left(\mathrm{mg} \mathrm{cm}^{-2}\right)$ ranging from 0.67 to 7.44 , which constitute the lowest recorded rate. No statistically significant difference was observed between the GDR values in the late winter, spring, and summer; however, the mean differences between the fall and winter seasons were statistically significant.

\subsection{WRF-Chem Model Output}

Figure 7 shows the WRF-modeled wind rose diagrams for the deposition sites for the two simulation periods in 2014 and 2015.

The general patterns of the wind rose diagrams for both the simulation periods are reasonably similar. The predominant wind directions can be noticed along the northwest to the southeast, particularly for G08, G09, and G10, which are located in the depositional plain of the south. These predominant wind directions are consistent with the simulated dust concentration by the WRF-Chem model.

At the outset, soil erodibility is one of the main contributing factors in the modeling of dust emission flux. Regarding that the WRF-Chem soil erodibility variable is based on a global equation [26], 
correction of this variable will have a significant impact on the model's results of the dust emission and deposition rates (Figure 8).

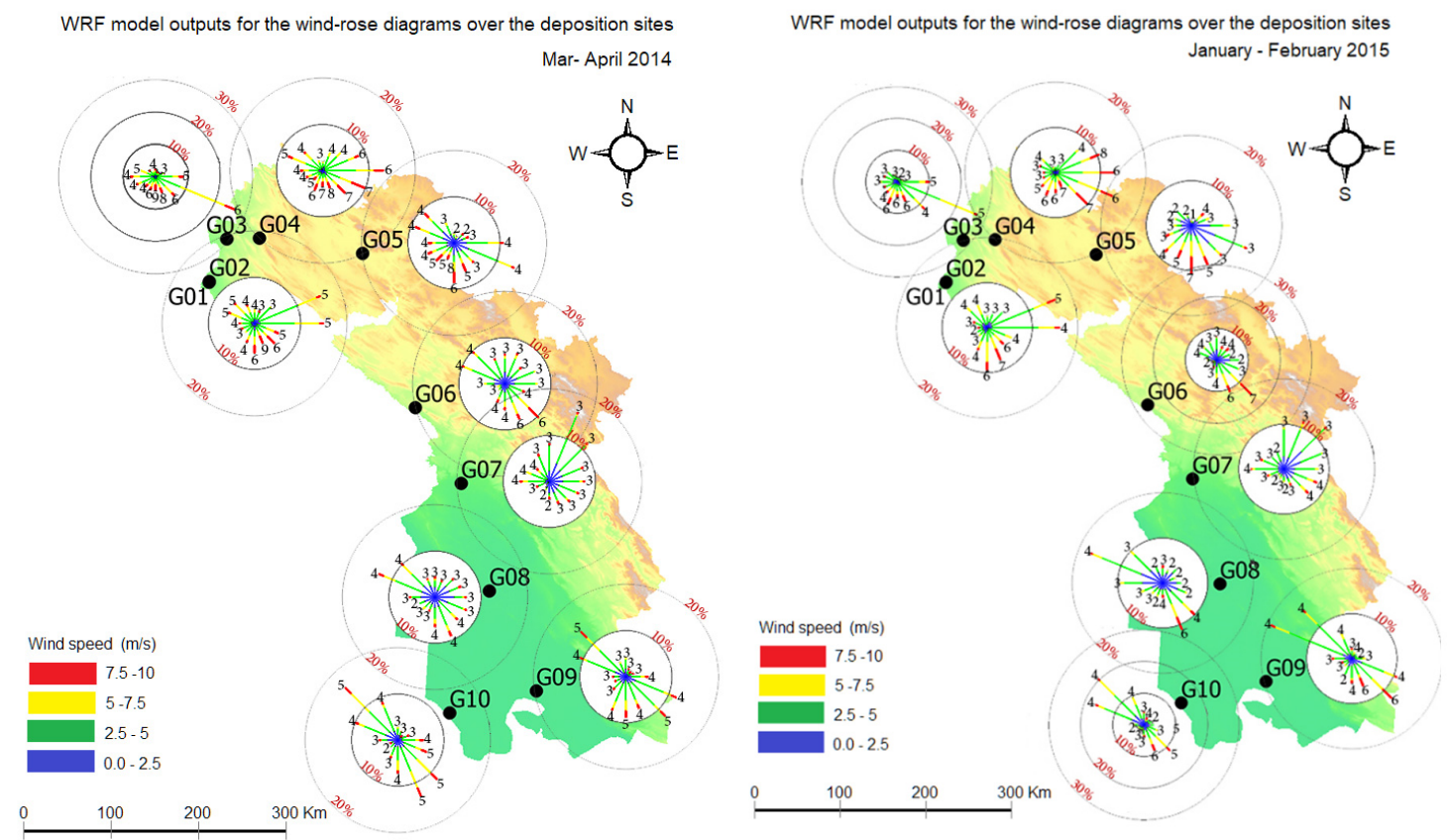

Figure 7. WRF model outputs for the wind rose diagrams.

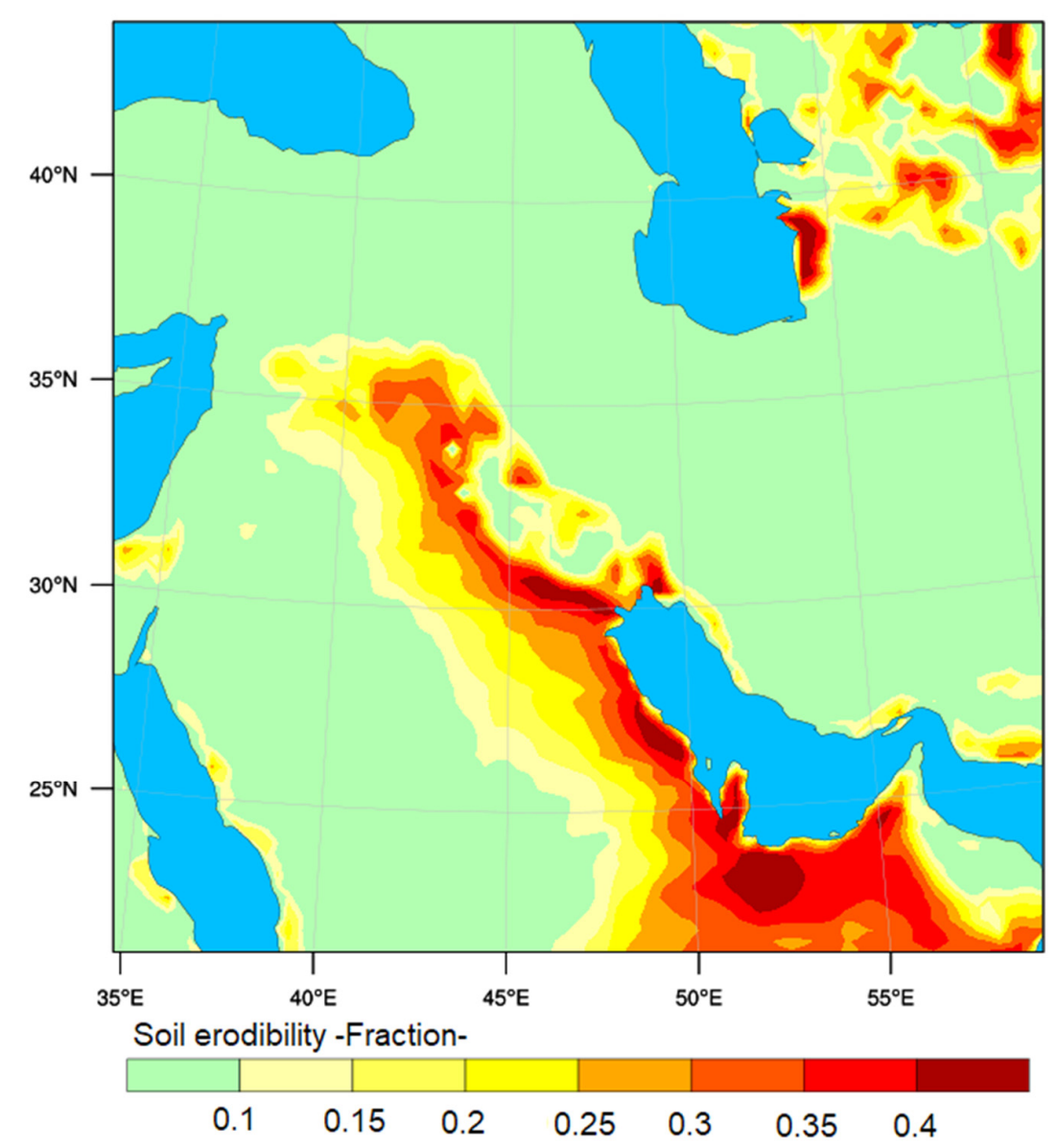

Figure 8. Soil erodibility map between $45^{\circ} 30^{\prime} 00^{\prime \prime} \mathrm{E}$ and $49^{\circ} 30^{\prime} 00^{\prime \prime} \mathrm{E}$ and between $30^{\circ} 00^{\prime} 00^{\prime \prime} \mathrm{N}$ and $35^{\circ} 00^{\prime} 00^{\prime \prime} \mathrm{N}$. 
Figure 9 illustrates the contour maps of the simulated dust concentrations $\left(\mu \mathrm{g} \mathrm{m}^{-3}\right)$ over the second domain (subdomain) of the WRF model. Outputs of the weather simulations are set with an interval of $1 \mathrm{~h}$; however, to enhance the existing data visualization, each image in Figure 9 represents a 20 -day average value of the dust concentration. In Figure $9 a-f$, regions with higher dust concentrations, depicted as red contours, are noticeable over the southern parts of the second simulation domain in G10, G09, G08, and G07. A reason for this pattern may be the soil erosion fields, which cover considerably large areas in the south. In comparison, in the northern parts with mountainous terrains and high altitudes, the soil sediments of the aeolian and fluvial processes cannot be accumulated, and, hence, dust sources are not expected to form in such regions.

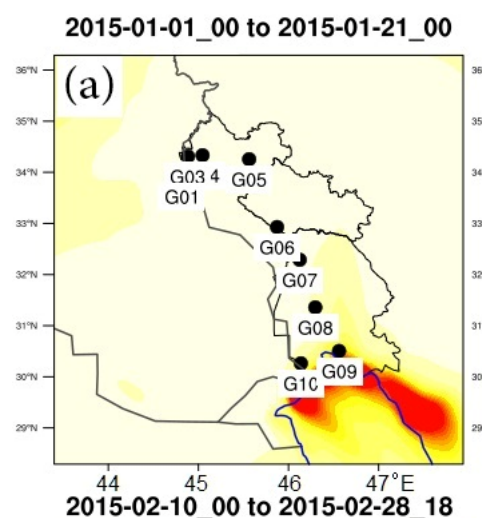

2015-01-21_00 to 2015-02-10_00
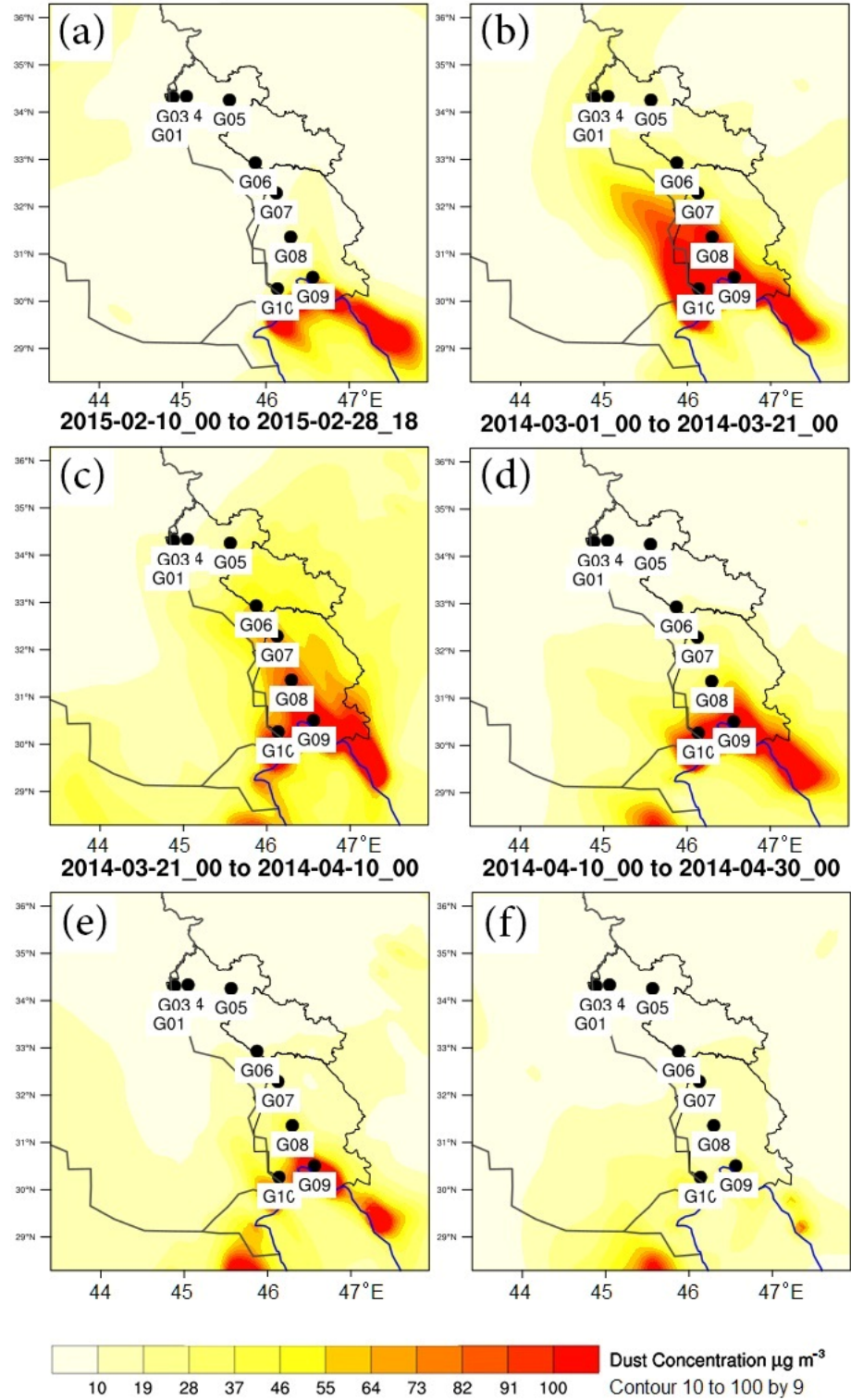

Figure 9. WRF-Chem results for concentrations $\left(\mu \mathrm{g} \mathrm{m}^{-3}\right)$. Outputs of the weather simulations are set with an interval of 1 hour. To enhance the existing data visualization, each image in (a-f) represents a 20-day average value of the dust concentration.

For further investigation of the WRF-Chem results and variations in the simulated dust load, the time series of the modeled dust loads for the two simulation periods are depicted in Figure 10a-f. 

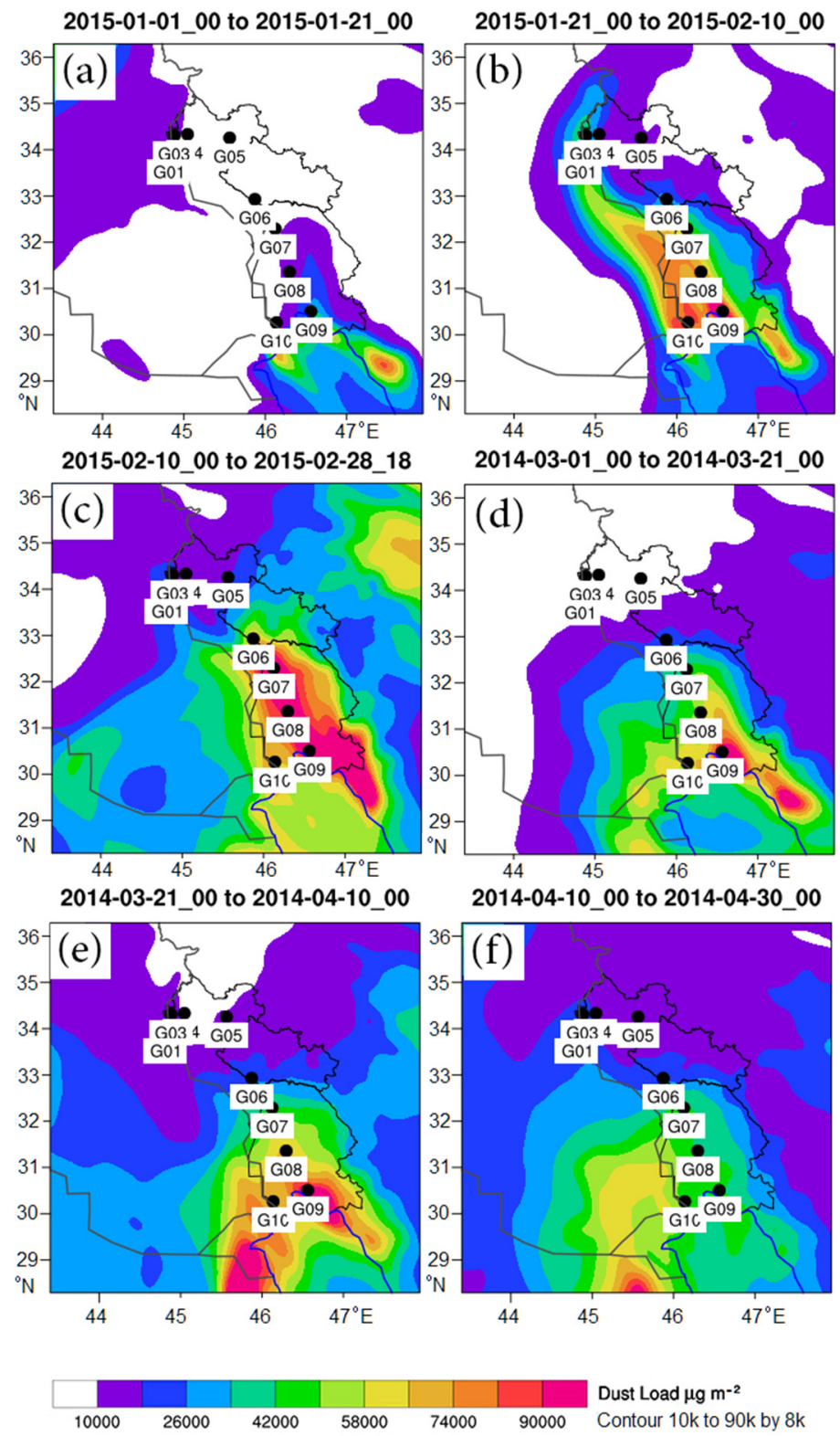

Figure 10. WRF-Chem results for the load $\left(\mu \mathrm{g} \mathrm{m}^{-2}\right)$. To enhance the existing data visualization, each image in (a-f) represents a 20-day average value of the dust load.

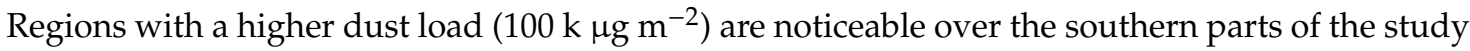
area. The dust load increased from the region in Figure 10b to the region in Figure 10c in 2015 and increased slightly from the region in Figure 10d to the region in Figure 10e in 2014. However, in the

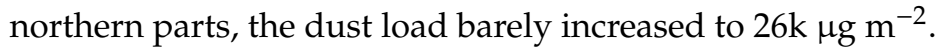

\section{Discussion}

\subsection{Field Experiment and Classification Part of Discussion}

This section discusses the deposition rates based on the LULC classification, climate factors, and GDR data and provides a better interpretation of the overall influence of the deposition rate on the WRF-Chem model output under the three scenarios. To assess the LULC and climate offset for each gauge site, areas with the same climate zone were classified for analysis. A dendrogram is the most commonly used method for cluster analysis (Figure 11). 


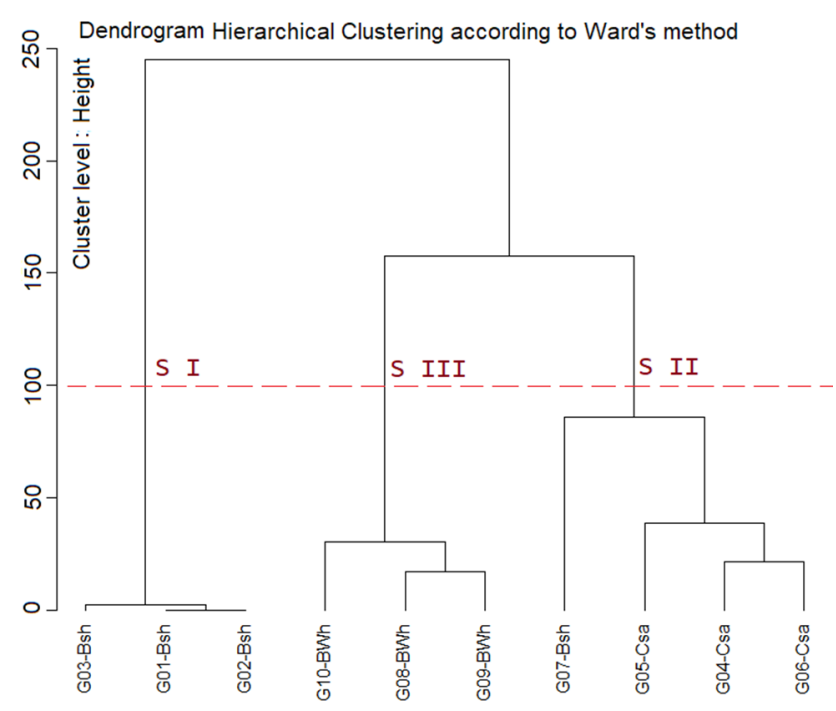

Figure 11. Hierarchical relationships among the LULC, gauge sites, and climate zones. Clustering analysis was performed following Ward's method (e.g., [53]). The study area was classified into three exclusive scenarios based on a combination of internal variables, such as the climate patterns, and this classification was applied to identify different LULC groups by clustering sites with similar climate patterns.

Based on the maximum likelihood classification the first scenario, S.I, for the three gauges is considered as [S.I - G01, G02, and G03] under the BSh Climate. The csa climate zone in the second scenario (S.II) covers four gauge sites, depicted as [S.II-G04, G05, G06, and G07]. For the third scenario (S.III), however, [S.III-G08, G09, and G10] are clustered in the BWh climate zone.

Seasonal ground-based observations showed that the highest dust deposition rates ranged from 1.45 to $1.7 \mathrm{mg} \mathrm{cm}^{-2}$, with a mean value of $1.1 \mathrm{mg} \mathrm{cm}^{-2}$ occurring in the spring (April) and that of $1.45 \mathrm{mg} \mathrm{cm}^{-2}$ in late winter at [S.III-G09, G10]. The maximum mean of the GDR values was recorded in the following order: spring (1.2), summer $(1.0)$, winter $(0.8)$, and autumn $(<0.5)$. The lowest deposition rates, of $0.35 \mathrm{mg} \mathrm{cm}^{-2}$, in autumn were reported for September and November and were located at [S.I-G01,G02, and G03] and [S.II-G06 and G07].

In the spring, the highest value $\left(1.49 \mathrm{mg} \mathrm{cm}^{-2}\right)$ was recorded in April for [S.III-G08 and G09] and the lowest value $\left(0.85 \mathrm{mg} \mathrm{cm}^{-2}\right)$ was recorded in May for [S.I-G03]. Similarly, in summer, for S.III, the maximum values of 1.49 and $1.45 \mathrm{mg} \mathrm{cm}^{-2}$ were obtained in June and July, respectively, whereas the minimum amount $\left(0.6 \mathrm{mg} \mathrm{cm}^{-2}\right)$ was observed in August. The minimum value remained the same from the late summer onward. Subsequently, it slightly increased in the autumn months, resulting in a maximum value $\left(0.8 \mathrm{mg} \mathrm{cm}^{-2}\right)$ at G10 and a minimum value $\left(0.3 \mathrm{mg} \mathrm{cm}^{-2}\right)$ in September and November at [S.II-G06 and G07]. Similarly, in winter, a high deposition rate $\left(1.2 \mathrm{mg} \mathrm{cm}^{-2}\right)$ was observed in [S.III-G09] in January, with the exception of a heavy dust event in late winter. In contrast, a minimum amount $\left(0.35 \mathrm{mg} \mathrm{cm}^{-2}\right)$ was recorded in December at [S.II—G07 and G06].

As shown in Figures 12 and 13, because of the short geographical distance between G01 and G02, the same grid point can represent both G01 and G02; therefore, they are expected to show the same values in the plot of the dust load and concentration.

The lowest dust load values [S.I-G03], [S.II-G04 and G05] were in the northernmost deposition sites, and the highest dust load values [S.III-G08, G09, and G10] were in the southernmost deposition sites.

\subsection{Model Combined in Each Site and Scenario}

The investigation of the dust load revealed that on the time series plot over any of the individual deposition sites, [S.II—G06 and G07], and [S.III—G08, G09, and G10] showed approximately the same 
patterns for the variations in the dust loads, and could be classified in the same group (Figure 12). For example, the blue column (February 10-20) and yellow column (April 1-10) correspond to the period with the highest dust load for almost all of the aforementioned sites. However, [S.I-G01, G02, and G03] show different variations in the dust load values. This contrast can be explained by the different geographical regions of these deposition sites, LULC, and climate patterns, which cause them to experience different dust episodes. Therefore, the WRF-Chem model may slightly underestimate the measured dust over the load area with a soil less susceptible to erosion [24,25]. Consistent with, e.g. Tao et al., (2012), [54], the correlation between the deposition rate and meteorological pattern indicates that high temperatures and lack of precipitation are the most significant factors behind a high dust deposition rate. Therefore, in the autumn and early winter seasons, the lower values of the meteorological parameters, such as temperature, and comparative wind direction, appear to be responsible for the lower deposition.
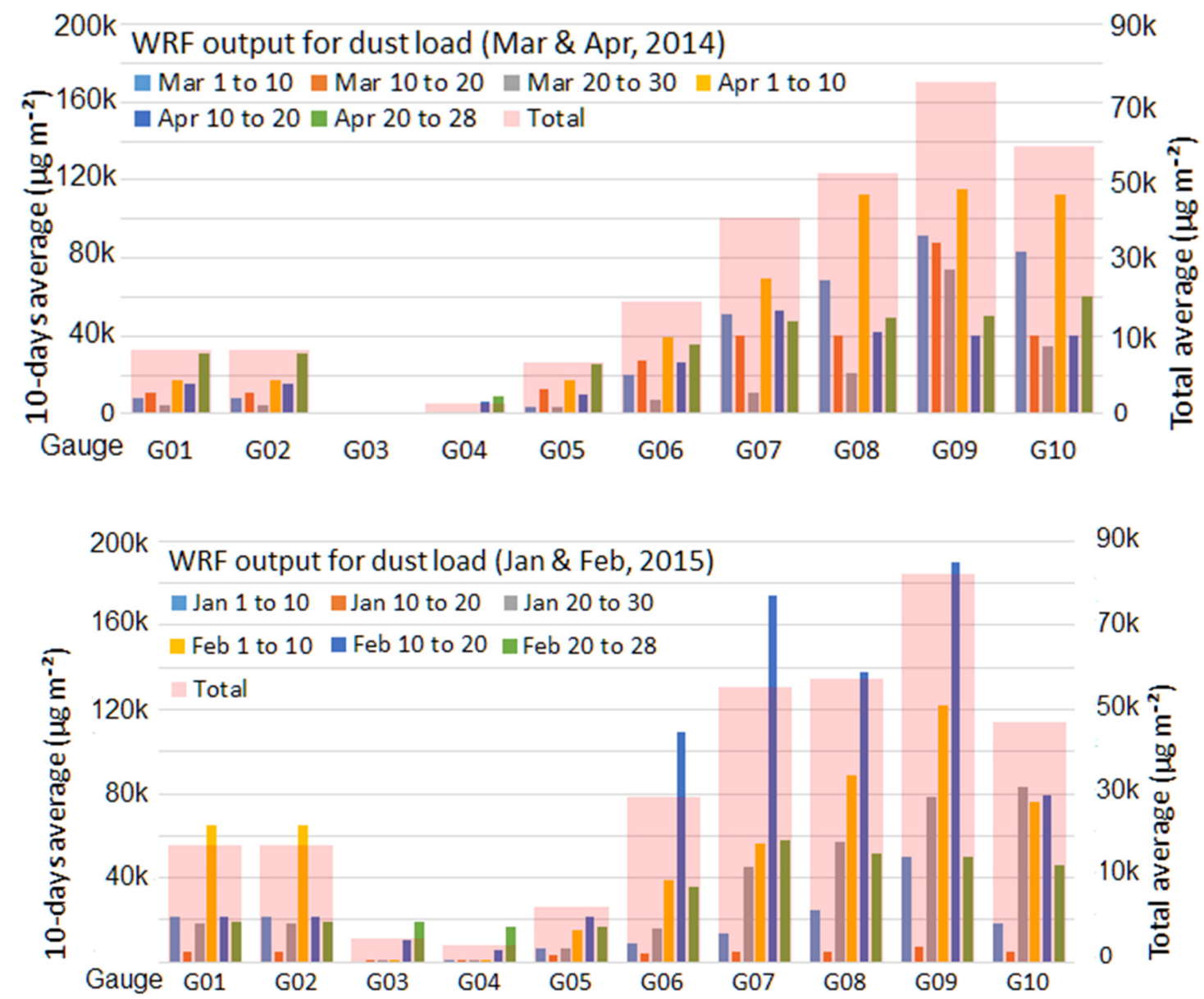

Figure 12. Time series of the 10-day average and total average modeled load $\left(\mu \mathrm{g} \mathrm{m}^{-2}\right)$. The time series plot of the modeled dust load is extracted from the WRF outputs using the nearest point method. The main Y-axis (left) represents the ten-day average values, whereas the secondary Y-axis (right) denotes the total average values.

As shown in Figure 13, the variation in the concentration values indicates the following sequence: [S.I-G01, G02, and G03] < [S.II-G04, G05, G06, and G07] < [S.III-G08, G09, and G10]. The lowest rates occurred in March and April 2014 for [S.I] (less than $10 \mu \mathrm{g} \mathrm{m}^{-3}$ ), [S.II] (slightly above $10 \mu \mathrm{g} \mathrm{m}^{-3}$ ), and [S.III] (approximately $160 \mu \mathrm{g} \mathrm{m}^{-3}$ ). Similarly, with the same trend in January and February 2015, the lowest rates were approximately $20 \mu \mathrm{g} \mathrm{m}^{-3}$ for [S.I], slightly less than $40 \mu \mathrm{g} \mathrm{m}^{-3}$ for [S.II], and approximately $250 \mu \mathrm{g} \mathrm{m}^{-3}$ for [S.III-]. 

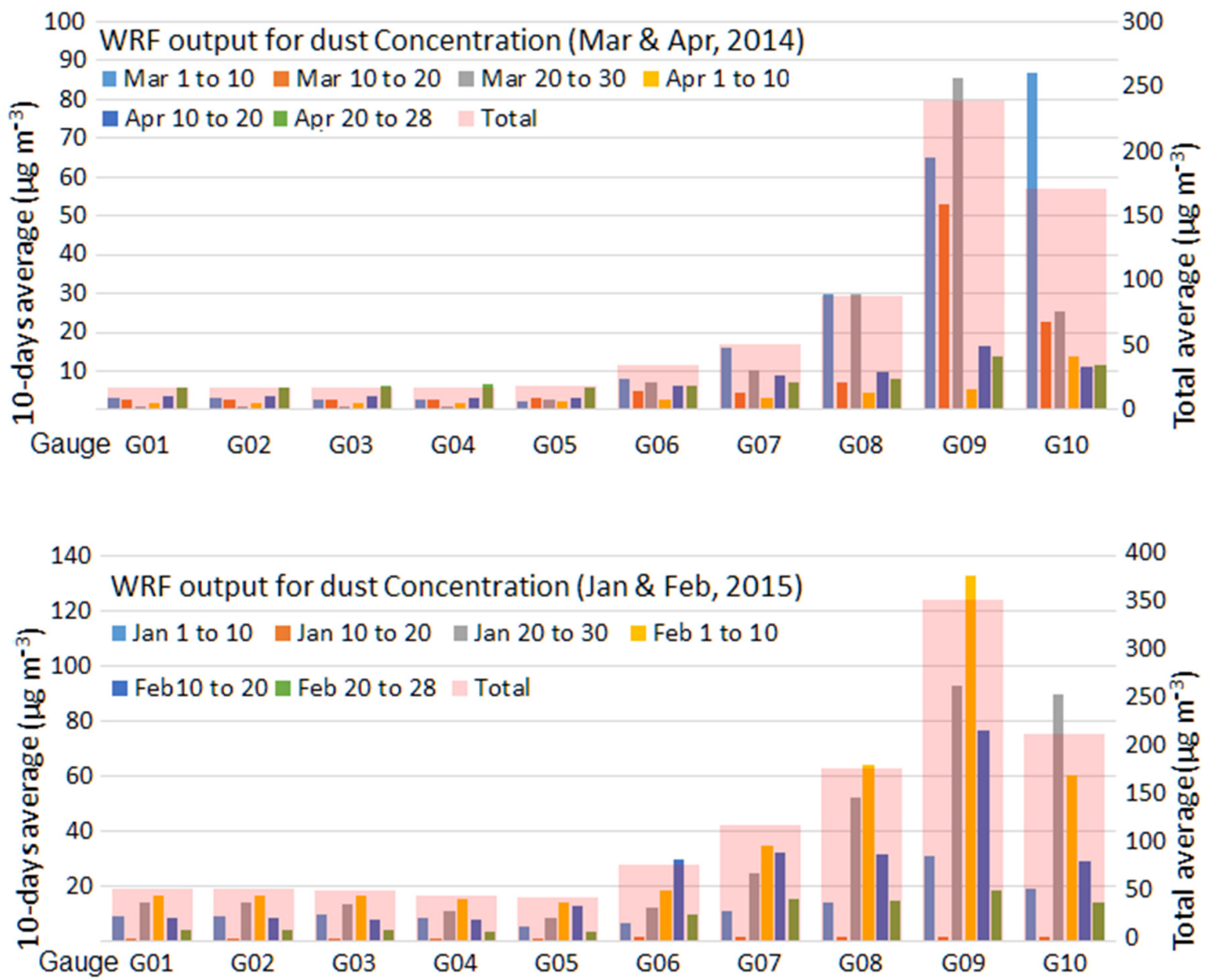

Figure 13. Time series of the 10-day average and the total average modeled concentration $\left(\mu \mathrm{g} \mathrm{m}^{-3}\right)$.

A statistical comparison of the GDR and model results for both the load and concentration values over the study area was performed to reveal the true correlation and evaluate the rate factor from the model output. A strong positive correlation was presented by the WRF-Chem model for the dust load during January-February $2015(80 \%)$, at 0.004 ( $p$-value). The probability level and correlation lines showed a line-wise match (a perfect match line). In contrast, in the winter, the correlation coefficient between the GDR and WRF-Chem data for March-April 2014 (62\%) was calculated to have a $p$-value of 0.032 . This contribution is consistent with previous research, suggesting that different land surface and the climate patterns influence the regional aeolian dust budget and its interaction in the climate system $[14,15]$. Moreover, as illustrated in Figure 14B, the correlation coefficients between the GDR data and WRF-Chem model for the dust concentration during January-February 2015 (75\%) and March-April 2014 (76\%) have $p$-values of 0.012 and 0.009 (Figure 14D), respectively. This contribution is reinforced by the rate factor of the dust deposition and by the correlation coefficient between the dust-in-suspension level (WRF-Chem for dust) and the deposition rate (GDR). This rate is altered when dust travels from the south points to the northwest points. 

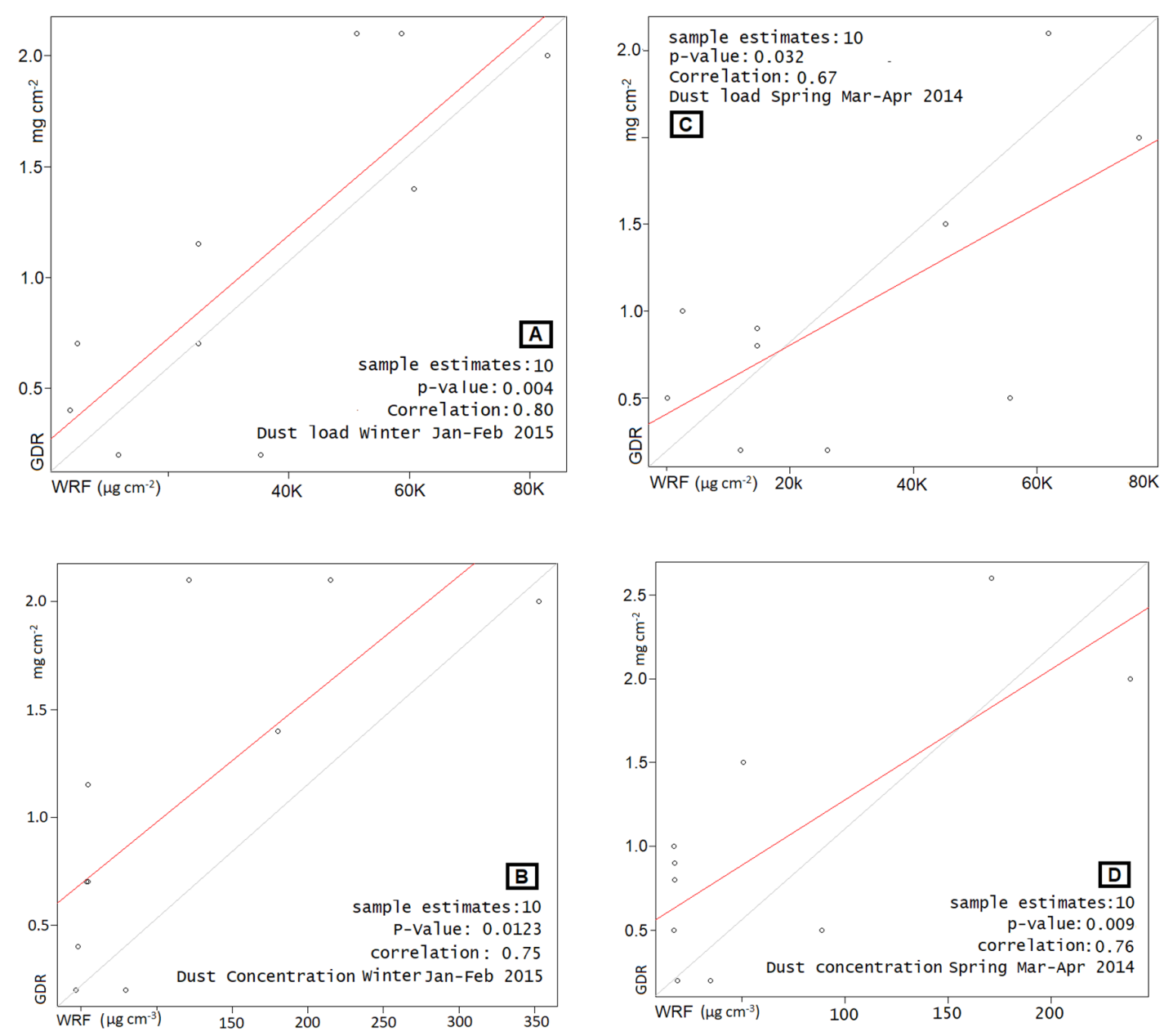

Figure 14. Correlation plot of the WRF-Chem versus the GDR observation. Scatter plot between GDRs (observation) and WRF-Chem (model output) illustrates that for the dust load (A) and dust concentrations (B) in January 2015 on the left and the correlation coefficient value in spring 2014 for the dust load (C) and concentration (D) on the right side.

Atmospheric variables, such as temperature and precipitation, are sensitive to land-surface properties and land-atmosphere interactions $[55,56]$. Chronological changes over the land surface are presented under all the conditions, as determined by natural and artificial forcing factors. Yap and Oke, [57] suggested that a reasonable heat flux was mainly determined by the differential temperature, emitting from the land surface to the atmosphere. Overall, the interactions between the various attributes, such as the climate pattern and topology, are influenced by the deposition rate. Therefore, the dust deposition rates and climate are expected to differ in different regions. The production and movement of the aeolian material through the atmosphere vary in response to large-scale climatic features [58]. In particular, topology factors, e.g., the vicinity to high elevation and mountainous areas in the east and north, result in biased deposition rates in the north. In addition, with LULC, bare lands, wetlands, urbanization, and vegetation can be used to subjectively define the rate at the dust sampling sites. Locations close to construction or far from roads appear to affect the quantity and quality of the dust. Therefore, for the given three scenarios (S.I-S.III), a combination of climate variables is applied to the gauge sites.

\subsection{Finding and Importance of Ground Deposition}

The first scenario [S.I-G01, G02, and G03], with an average of $40^{\circ} \mathrm{C}$ in the summer and an annual precipitation of $170 \mathrm{~mm}$, is mostly comprised of eastward dusty winds. The prevailing wind directions 
are west to east, with northwest and southwest fluctuations. This scenario reveals that more than $99 \%$ of the land is bare land and land that extends within the borders of Iraq follows the same pattern. As the dust load and concentration increase, the rate factor poorly represents the deposition rate over the gauge sites [S.I—G01, G02, G03]. The high-speed eastward wind may have impacted the reading from the model output.

The second scenario [S.II-G04, G05, G06, and G07] covers a part of the study area in the south (G07), which has been suffering from significant increases in dust. G04, G05, and G06 had only small dust events. Despite the identical climate over S.II, various land use land surfaces are present. Although G04 and G06 are represented by bare land (48\%) and vegetation (27\%), G05 contains 32\%, 33\%, and 34\% of vegetation, artificial, and bare lands, respectively. G07 is an exception, as it is represented by mixed vegetation $(77 \%)$, waterbodies $(8 \%)$, and artificial land $(4 \%)$. Numerous studies have focused on the influence of LULC on atmospheric properties and their processes, e.g., boundary layer dynamics, convection, cloud properties [59], and precipitation [60].

The impact of the land surface on precipitation is complex and tends to induce both increased and decreased precipitation. For the urbanization scenario, the simulation shows that the average temperature will be increased by $1.2-4{ }^{\circ} \mathrm{C}$ if the study area is entirely urbanized [15].

Thus, urbanization influences the exchange values of water and energy between the land and atmosphere, due to changes in the surface roughness and soil moisture. In addition, large aerosol emissions in urban areas absorb a large amount of solar shortwave radiation and lead to reduced albedo [61]. Therefore, the low albedo can be a major reason for changes in the temperature. Albedo further refers to the fraction of the solar energy reflected from the land surface to the atmosphere [62]. Kueppers [63] suggested that urbanization would significantly impact the heat fluxes between the land and atmosphere.

Wetland areas have substantially altered evapotranspiration and runoff, which influences the heat exchange [64]. This can cause shifts of land use to croplands, i.e., the structure and function of the vegetation layer can change and the energy flux in the climate system is influenced. This change is consistent with that observed previous studies that suggested that irrigation could potentially increase precipitation [65]. During the period with increasing dust load, a narrow gap between the dust concentration and deposition rates over the gauge sites [S.II] was weak. The high-altitude Zagros Mountains, however, have negatively affected the impact of the deposition rate at the gauge sites [S.II-G07, G06, G05, and G04].

In the third scenario (S.III), frequent dust events occurring over decades were attributed by the spatial analysis that showed that the dust pattern extended across the area from a dusty region in Iraq, Saudi Arabia, and Syria and reached southwest Iran every year, particularly during the hot season $[66,67]$. Aeolian dust was blown from beyond the national border and the aeolian deposition rate has continued to be a major crisis caused by the low topography and extremely warm and arid climate, which reaches over $55{ }^{\circ} \mathrm{C}$ in the summer with an annual $(100-150 \mathrm{~mm})$ deficit of rainfall. While one third of the area over G10 is bare land (36\%), the remaining is composed of vegetation (15\%), artificial $(25 \%)$, and wetlands $(22 \%)$. The covered areas serve as obstacles for dust and trap dust when the wind is not sufficiently strong. As can be seen in the last scenario, the areas in G08 and G09 include vegetation (33\% and 19\%, respectively), artificial areas ( $8 \%$ and $9 \%$, respectively), and bare lands (58\% and $60 \%$, respectively). Consistent with the results of Daniali and Karimi, (2019) [68], as the dust load increases, a positive ratio exists between the dust concentration and deposition rate over the gauge sites [S.III-G10, G09, and G08].

\section{Conclusions}

The seasonal dust deposition rate was investigated using the WRF-Chem model to predict the deposition rate of the dust load and the concentration of dust over southwest Iran between 2014 and 2015. The model simulation results were combined with the GDRs and surface meteorological variables at 10 gauge sites. The results of the deposition rate for the three scenarios [S.I, S.II, and S.III] 
is discussed. S.III exhibited the highest amount of dust, whereas the minimum value was recorded over S.I and S.II.

The analyses indicate that the WRF-Chem model adequately simulates the evolution and spatial distributions of the rate factor over the study area. Although this contribution demonstrates that the WRF-Chem model has significant potential to simulate dust storms, the results reveal decreasing amount of dust load from the southern to the northern points. This indicates a narrowing of the gap between the modeling results and GDR data. The dust concentration and dust load poorly represent the increase in dust particles when moving to lower altitudes or the increase in the dust resident time at high altitudes. The results provide useful guidance for early warnings systems and risk reduction of dust events under various environmental conditions.

The strongest positive correlation between the WRF-Chem model results and GDR data was found for the concentration in the spring, with a correlation coefficient of $76 \%$ and $p=0.0123$. Similarly, a strong correlation for the dust load in the winter (80\%) was noted, with $p=0.004$. This combination is an important data source and can be a relevant subject for studies in this field. In practice, however, unlike with corresponding observations from dust deposition rates (GDRs), the WRF-Chem results show decreases in the dust load and concentrations from the southwest [S.III] to the northwest [S.I] due to the model prediction of dust movement at higher altitudes; for example, the rate factor in [S.II] was higher and the rate factor in [S.I] was lower rate compared with the dust deposition rate captured from GDRs.

The results from this study are consistent with those of previous reviews and show that physical characteristics and gradient distributions are not well known; therefore, a consistent effort is needed to improve our predictions. The capacity of the WRF-Chem to model dust based on GDRs over a study area suggests that future investigations can accurately predict GDRs from the prediction model. Therefore, GDR data can increase the accuracy of the estimations, whereas an appropriate algorithm is necessary to enhance the affected area exposed to dust.

Author Contributions: Conceptualization, M.A.F., and M.G.; methodology, M.A.F., and C.O.; software, M.A.F., A.N.; validation, M.A.F., A.N., and C.O.; formal analysis, and investigation, M.A.F.; resources, data curation, and writing—original draft preparation, M.A.F., A.N.; writing—review and editing, M.A.F.; visualization, M.A.F, A.N.; supervision, C.O., and M.G.; project administration, C.O.; funding acquisition, M.A.F. All authors have read and agreed to the published version of the manuscript.

Funding: This work did not receive any specific grant from funding agencies in the public, commercial, or not-for-profit sectors.

Acknowledgments: We wish to acknowledge the cooperation of IOPTC, experts in the home country during the conduction of the fieldwork. We also wish to acknowledge Alireza Rezaei Barmi and his scientific contributions to the preparation and operation of the instruments.

Conflicts of Interest: The authors declare no conflict of interest.

\section{References}

1. Gold, V.; Loening, K.L.; McNaught, A.D.; Shemi, P.; Wilkinson, A. Glossary of atmospheric chemistry terms. Pure Appl. Chem. 1990, 62, 2167-2219.

2. Charlson, R.; Schwartz, S.E.; Hales, J.M.; Cess, R.D.; Coakley, J.J.; Hansen, J.E.; Hofmann, D.J. Climate forcing by anthropogenic aerosols. Science 1992, 255, 423-430. [CrossRef]

3. Prospero, J.M.; Ginoux, P.; Torres, O.; Nicholson, S.E.; Gill, T.E. Environmental characterization of global sources of atmospheric soil dust identified with the Nimbus 7 Total Ozone Mapping Spectrometer (TOMS) absorbing aerosol product. Rev. Geophys. 2002, 40, 2-31. [CrossRef]

4. Tegen, I.; Werner, M.; Harrison, S.P.; Kohfeld, K.E. Relative importance of climate and land use in determining present and future global soil dust emission. Geophys. Res. Lett. 2004, 31, 5. [CrossRef]

5. Amiridis, V.; Wandinger, U.; Marinou, E.; Giannakaki, E.; Tsekeri, A.; Basart, S.; Kazadzis, S.; Gkikas, A.; Taylor, M.; Baldasano, J.; et al. Optimizing CALIPSO Saharan dust retrievals. Atmos. Chem. Phys. 2013, 13, 12089-12106. [CrossRef] 
6. Chen, Y.S.; Sheen, P.C.; Chen, E.R.; Liu, Y.K.; Wu, T.N.; Yang, C.Y. Effects of Asian dust storm events on daily mortality in Taipei, Taiwan. Environ. Res. 2004, 95, 151-155. [CrossRef]

7. Groll, M.; Opp, C.; Aslanov, I. Spatial and temporal distribution of the dust deposition in Central Asia-results from a long term monitoring program. Aeolian Res. 2013, 9, 49-62. [CrossRef]

8. Opp, C.; Groll, M.; Aslanov, I.; Lotz, T.; Vereshagina, N. Aeolian dust deposition in the southern Aral Sea region (Uzbekistan): Ground-based monitoring results from the LUCA project. Quat. Int. 2017, 429, 86-99. [CrossRef]

9. Stefanski, R.; Sivakumar, M.V.K. Impacts of sand and dust storms on agriculture and potential agricultural applications of a SDSWS. In Proceedings of the IOP Conference Series: Earth and Environmental Science, Bristol, UK, March 2009. Available online: https://iopscience.iop.org/article/10.1088/1755-1307/7/1/012016 (accessed on 18 June 2020).

10. Ohde, T.; Siegel, H. Impacts of Saharan dust and clouds on photosynthetically available radiation in the area off Northwest Africa. Tellus Ser. B-Chem. Phys. Meteorol. 2012, 64, 17160. [CrossRef]

11. Schepanski, K.; Heinold, B.; Tegen, I. Harmattan, Saharan. heat low, and West African monsoon circulation: Modulations on the Saharan dust outflow towards the North Atlantic. Atmos. Chem. Phys. 2017, 17, 10223-10243. [CrossRef]

12. Skamarock, W.; Klemp, J.; Dudhia, J.; Gill, D.; Barker, D.; Duda, M.; Powers, J. Description of the Advanced Research WRF Version 3; National Center for Atmospheric Research Technical: Boulder, CO, USA, June 2008.

13. Mandal, M.; Mohanty, U.C.; Raman, S. A study on the impact of parameterization of physical processes on prediction of tropical cyclones over the Bay of Bengal with NCAR/PSU mesoscale model. Nat. Hazards 2004, 31, 391-414. [CrossRef]

14. Carvalho, D.; Rocha, A.; Gómez-Gesteira, M.; Santos, C.S. WRF wind simulation and wind energy production estimates forced by different reanalyses: Comparison with observed data for Portugal. Appl. Energy 2014, 117, 116-126. [CrossRef]

15. Li, N.; Long, X.; Tie, X.; Cao, J.; Huang, R.; Zhang, R.; Feng, T.; Liu, S.; Li, G. Urban dust in the Guanzhong basin of China, part II: A case study of urban dust pollution using the WRF-Dust model. Sci. Total Environ. 2016, 541, 1614-1624. [CrossRef] [PubMed]

16. Hahnenberger, M.; Nicoll, K. Geomorphic and land cover identification of dust sources in the eastern Great Basin of Utah, USA. Geomorphology 2014, 204, 657-672. [CrossRef]

17. Huang, J.; Wang, T.; Wang, W.; Li, Z.; Yan, H. Climate effects of dust aerosols over East Asian arid and semiarid regions. J. Geophys. Res. Atmos. 2014, 119, 11398-11416. [CrossRef]

18. Chen, B.; Stein, A.F.; Maldonado, P.G.; de la Campa, A.M.S.; Gonzalez-Castanedo, Y.; Castell, N.; Jesus, D. Size distribution and concentrations of heavy metals in atmospheric aerosols originating from industrial emissions as predicted by the HYSPLIT model. Atmos. Environ. 2013, 71, 234-244. [CrossRef]

19. Nabavi, S.O.; Haimberger, L.; Samimi, C. Sensitivity of WRF-chem predictions to dust source function specification in West Asia. Aeolian Res. 2017, 24, 115-131. [CrossRef]

20. Chen, S.; Zhao, C.; Qian, Y.; Leung, L.R.; Huang, J.; Huang, Z.; Bi, J.; Zhang, W.; Shi, J.; Yang, L.; et al. Regional modeling of dust mass balance and radiative forcing over East Asia using WRF-Chem. Aeolian Res. 2014, 15, 15-30. [CrossRef]

21. Huang, J.; Minnis, P.; Yan, H.; Yi, Y.; Chen, B.; Zhang, L.; Ayers, J.K. Dust aerosol effect on semi-arid climate over Northwest China detected from A-Train satellite measurements. Atmos. Chem. Phys. 2010, 10, 6863-6872. [CrossRef]

22. Beres, J.H.; Garcia, R.R.; Boville, B.A.; Sassi, F. Implementation of a gravity wave source spectrum parameterization dependent on the properties of convection in the Whole Atmosphere Community Climate Model (WACCM). J. Geophys. Res. Atmos. 2005, 110. [CrossRef]

23. Koren, I.; Kaufman, Y.J.; Washington, R.; Todd, M.C.; Rudich, Y.; Martins, J.V.; Rosenfeld, D. The Bodélé depression: A single spot in the Sahara that provides most of the mineral dust to the Amazon forest. Environ. Res. Lett. 2006, 1. [CrossRef]

24. Todd, M.C.; Bou Karam, D.; Cavazos, C.; Bouet, C.; Heinold, B.; Baldasano, J.M.; Cautenet, G.; Koren, I.; Perez, C.; Solmon, F.; et al. Quantifying uncertainty in estimates of mineral dust flux: An intercomparison of model performance over the Bodélé Depression, northern Chad. J. Geophys. Res. Atmos. 2008, 113. [CrossRef] 
25. Bullard, J.E.; Harrison, S.P.; Baddock, M.C.; Drake, N.; Gill, T.E.; McTainsh, G.; Sun, Y. Preferential dust sources: A geomorphological classification designed for use in global dust-cycle models. J. Geophys. Res. Earth Surf. 2011, 116. [CrossRef]

26. Ginoux, P.; Chin, M.; Tegen, I.; Prospero, J.M.; Holben, B.; Dubovik, O.; Lin, S.J. Sources and distributions of dust aerosols simulated with the GOCART model. J. Geophys. Res. Atmos. 2001, 106, 20255-20273. [CrossRef]

27. Rashki, A.; Eriksson, P.G.; Rautenbach, C.D.W.; Kaskaoutis, D.G.; Grote, W.; Dykstra, J. Assessment of chemical and mineralogical characteristics of airborne dust in the Sistan region, Iran. Chemosphere 2013, 90, 227-236. [CrossRef]

28. Foroushani, M.A.; Opp, C.; Groll, M. Chemical Characterization of Aeolian Dust Deposition in Southern and Western Iran. Asian J. Geogr. Res. 2019, 2, 1-22. [CrossRef]

29. Goudie, A.S.; Middleton, N.J. Saharan dust storms: Nature and consequences. Earth-Sci. Rev. 2001, 56, 179-204. [CrossRef]

30. Schleicher, N.J.; Norra, S.; Chai, F.; Chen, Y.; Wang, S.; Cen, K.; Yu, Y.; Stüben, D. Temporal variability of trace metal mobility of urban particulate matter from Beijing-A contribution to health impact assessments of aerosols. Atmos. Environ. 2011, 45, 7248-7265. [CrossRef]

31. Choobari, O.A.; Zawar-Reza, P.; Sturman, A. Feedback between windblown dust and planetary boundary-layer characteristics: Sensitivity to boundary and surface layer parameterizations. Atmos. Environ. 2012, 61, 294-304. [CrossRef]

32. Global Ambient Air Pollution, World Health Organization. 2018. Available online: https://www.who.int/ quantifying_ehimpacts/global/source_apport/en/ (accessed on 18 June 2020).

33. Almasi, A.; Mousavi, A.R.; Bakhshi, S.; Namdari, F. Dust storms and environmental health impacts. J. Middle East Appl. Sci. Technol. 2014, 8, 353-356.

34. Peel, M.C.; Finlayson, B.L.; McMahon. Updated world map of the Köppen-Geiger climate classification. Hydrol. Earth Syst. Sci. 2007, 11, 1633-1644. [CrossRef]

35. Iran Meteorological Organization. Precipitation Map. 2014. Available online: http://www.irimo.ir/index. php?newlang=eng (accessed on 25 January 2014).

36. NASA; METI; AIST; Japan Spacesystems; US/Japan ASTER Science Team. ASTER Global Digital Elevation Model (GDEM). 2001. Available online: https://doi.org/10.5067/aster/ast14dem.003 (accessed on 15 December 2017).

37. Russell, R. Dry Climates of the United States. Part I; The Climatic Map. Univ. of California; University of California Press: Berkeley, CA, USA, 1931.

38. Kriticos, D.J.; Webber, B.L.; Leriche, A.; Ota, N.; Macadam, I.; Bathols, J.; Scott, J.K. CliMond: Global high-resolution historical and future scenario climate surfaces for bioclimatic modelling. Methods Ecol. Evol. 2012, 3, 56-64. [CrossRef]

39. IHS under License with ASTM. "Standard Terminology Relating to Sampling and Analysis of Atmospheres," IHS License ASTM. 2010. Available online: https://wenku.baidu.com/view/8324a4b765ce050876321358 (accessed on 27 January 2014).

40. ASTM D1356, Standard Terminology Relating to Sampling and Analysis of Atmospheres, Subcommittee D22.03. 2017. Available online: https://standards.globalspec.com/std/10195132/ASTM\%20D1356 (accessed on 15 December 2017).

41. Parsa, V.A.; Yavari, A.; Nejadi, A. Spatio-temporal analysis of land use/land cover pattern changes in Arasbaran Biosphere Reserve: Iran. Model. Earth Syst. Environ. 2016, 2, 1-13. [CrossRef]

42. Verburg, P.H.; Schot, P.P.; Dijst, M.J.; Veldkamp, A. Land use change modelling: Current practice and research priorities. GeoJournal 2004, 61, 309-324. [CrossRef]

43. Taghavia, F.; Mohammadi, H. The survey of linkage between climate changes and desertification using extreme climate index software. Desert 2008, 13,9-17.

44. Grell, G.A.; Peckham, S.E.; Schmitz, R.; McKeen, S.A.; Frost, G.; Skamarock, W.C.; Eder, B. Fully coupled 'online' chemistry within the WRF model. Atmos. Environ. 2005, 39, 6957-6975. [CrossRef]

45. Dee, D.P.; Uppala, S.M.; Simmons, A.J.; Berrisford, P.; Poli, P.; Kobayashi, S.; Andrae, U.; Balmaseda, M.A.; Balsamo, G.; Bauer, D.P.; et al. The ERA-Interim reanalysis: Configuration and performance of the data assimilation system, Q.J.R. Meteorol. Soc. 2011, 137, 553-597. [CrossRef]

46. Duce, R.A.; Unni, C.K.; Ray, B.J.; Prospero, J.M.; Merrill, J.T. Long-range atmospheric transport of soil dust from Asia to the tropical north pacific: Temporal variability. Science 1980, 209, 1522-1524. [CrossRef] 
47. Hoffmann, C.; Funk, R.; Wieland, R.; Li, Y.; Sommer, M. Effects of grazing and topography on dust flux and deposition in the Xilingele grassland, Inner Mongolia. J. Arid Environ. 2008, 72, 792-807. [CrossRef]

48. Song, C.H.; Park, M.E.; Ahn, H.J.; Lee, K.H.; Lee, Y.; Kim, J.Y.; Han, K.M.; Kim, J.; Ghim, Y.S.; Kim, Y.J. An investigation into seasonal and regional aerosol characteristics in East Asia using model-predicted and remotely-sensed aerosol properties. Atmos. Chem. Phys. Discuss. 2008, 8, 8661-8713. [CrossRef]

49. Ta, W.; Xiao, H.; Qu, J.; Xiao, Z.; Yang, G.; Wang, T.; Zhang, X. Measurements of dust deposition in Gansu Province, China, 1986-2000. Geomorphology 2004, 57, 41-51. [CrossRef]

50. Lenssen, N.J.; Schmidt, G.A.; Hansen, J.E.; Menne, M.J.; Persin, A.; Ruedy, R.; Zyss, D. Improvements in the GISTEMP Uncertainty Model. J. Geophys. Res. Atmos. 2019, 124, 6307-6326. [CrossRef]

51. Alizadeh-Choobari, O.; Najafi, M.S. Extreme weather events in Iran under a changing climate. Clim. Dyn. 2018, 50, 249-260. [CrossRef]

52. Al-Dousari, A.M.; Al-Awadhi, J. Dust fallout in northern Kuwait, major sources and characteristics. Kuwait J. Sci. Eng. 2012, 39, 171-187.

53. Yongming, H.; Peixuan, D.; Junji, C.; Posmentier, E.S. Multivariate analysis of heavy metal contamination in urban dusts of Xi'an, Central China. Sci. Total Env. 2006, 355, 176-186. [CrossRef]

54. Tao, W.K.; Chen, J.P.; Li, Z.; Wang, C.; Zhang, C. Impact of Aerosols on Convective Clouds and Precipitation. Rev. Geophys. 2012, 50. [CrossRef]

55. Hartig, E.K.; Grozev, O.; Rosenzweig, C. Climate change, agriculture and wetlands in Eastern Europe: Vulnerability, adaptation and policy. Clim. Chang. 1997, 36, 107-121. [CrossRef]

56. Shao, Y.; Wang, J. A climatology of Northeast Asian dust events. Meteorol. Z. 2003, 12, 187-196. [CrossRef]

57. Yap, D.; Timothy, R.O. Sensible heat fluxes over an urban area-Vancouver, BC. J. Appl. Meteorol. 1974, 13, 880-890. [CrossRef]

58. Dawson, J.P.; Bloomer, B.J.; Winner, D.A.; Weaver, C.P. Understanding the Meteorological Drivers of Us Particulate Matter Concentrations in a Changing Climate. Bull. Am. Meteorol. Soc. 2014, 95, 520-532. [CrossRef]

59. Ray, D.K.; Nair, U.S.; Welch, R.M.; Han, Q.; Zeng, J.; Su, W.; Kikuchi, T.; Lyons, T.J. Effects of land use in Southwest Australia: 1. Observations of cumulus cloudiness and energy fluxes. J. Geophys. Res.-Atmos. 2003, 108. [CrossRef]

60. Douglas, E.M.; Beltrán-Przekurat, A.; Niyogi, D.; Pielke Sr, R.A.; Vörösmarty, C.J. The impact of agricultural intensification and irrigation on land-atmosphere interactions and Indian monsoon precipitationA mesoscale modeling perspective. Glob. Planet. Chang. 2009, 67, 117-128. [CrossRef]

61. Weng, Q.; Lu, D.; Schubring, J. Estimation of land surface temperature-vegetation abundance relationship for urban heat island studies. Remote Sens. Environ. 2004, 89, 467-483. [CrossRef]

62. Royer, A.; Charbonneau, L.; Bonn, F. Urbanization and Landsat Mss Albedo Change in the Windsor Quebec Corridor since 1972. Int. J. Remote Sens. 1988, 9, 555-566. [CrossRef]

63. Kueppers, L.M.; Snyder, M.A.; Sloan, L.C.; Cayan, D.; Jin, J.; Kanamaru, H.; Weare, B. Seasonal temperature responses to land-use change in the western United States. Glob. Planet. Chang. 2008, 60, 250-264. [CrossRef]

64. Kalnay, E.; Cai, M. Impact of urbanization and land-use change on climate. Nature 2003, 423, 528-531. [CrossRef]

65. DeAngelis, A.; Dominguez, F.; Fan, Y.; Robock, A.; Kustu, M.D.; Robinson, D. Evidence of enhanced precipitation due to irrigation over the Great Plains of the United States. J. Geophys. Res. Atmos. 2010, 115. [CrossRef]

66. Mashayekhi, R.; Irannejad, P.; Feichter, J.; Bidokhti, A.A. Implementation of a new aerosol HAM model within the Weather Research and Forecasting (WRF) modeling system. Geosci. Model Dev. Discuss. 2009, 2, 681-707. [CrossRef]

67. Moorthy, K.K.; Satheesh, S.K.; Sarin, M.M.; Panday, A.K. South Asian aerosols in perspective: Preface to the special issue. Atmos. Environ. 2016, 125, 307-311. [CrossRef]

68. Daniali, M.; Karimi, N. Spatiotemporal analysis of dust patterns over Mesopotamia and their impact on Khuzestan province, Iran. Nat. Hazards 2019, 97, 259-281. [CrossRef]

(C) 2020 by the authors. Licensee MDPI, Basel, Switzerland. This article is an open access article distributed under the terms and conditions of the Creative Commons Attribution (CC BY) license (http://creativecommons.org/licenses/by/4.0/). 